\title{
السبب في قرارات الضبط الإداري وهدى الرقابة القضائية عليه
}

shel

د. يوسف ناصر حمد الظفيري

دكتوراه في القانون العام 


\section{טखil|}

يعد السبب أحد عناصر المشروعية الداخلية للقرار الإداري، فهو الحالة الواقعية

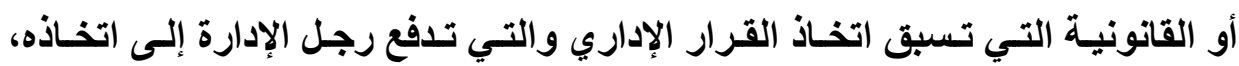

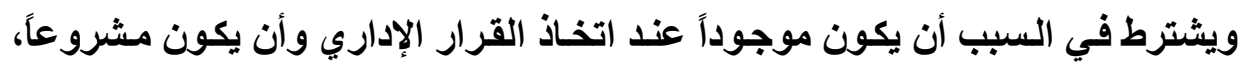

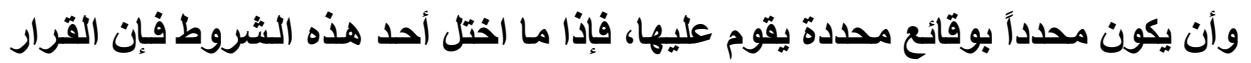
الإداري يكون باطلاً لعيب في السبب وعرضة للإلغاء من قبل القضاء الإداري. وتتجلى أسباب قرار الضبط الإداري في الوقائع الدافعة إلى اتخاذه، والتي تتبدى

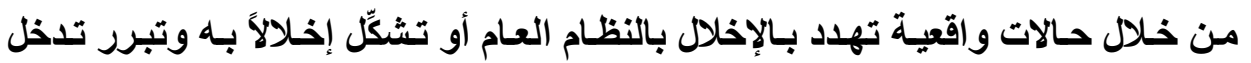
الإدارة لاتخاذ إجراء ضبطي. ونظراً لأن قرارات الضبط الإداري تمس بحقوق وحريات الأفراد، لذلك فإن مدى

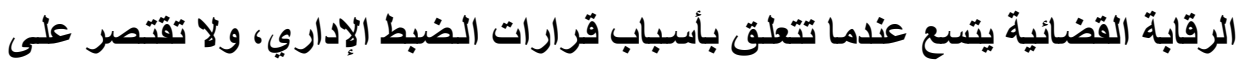

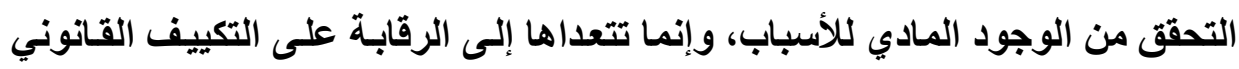
للأسباب، بل وتمتد إلى الرقابة على الملائمة أو التناسب. ويأتي هذا البحث لإيضاح ماهية السبب في قرارات الضبط الإداري ومدى اتساع نطاق الرقابة القضائية عليه. الكلمات المفتاحية: القرار الإداري، السبب في القرار الإداري، الضبط الإداري، النظام العام، الرقابة القضائية على أعمال الإدارة. 


\section{المقدهة}

يعرِّف الـكتور سليمان الطمساوي الضبط الإداري بأنسه:" حـق الإدارة في أن تفرض على الأفراد قيوداً تحد بها من حرياتهم بقصد حماية النظام العام "('). كما يعرّفه الدكتور طعيمة الجرف بأنه:" مجموعة ما تفرضه السلطة العامة من

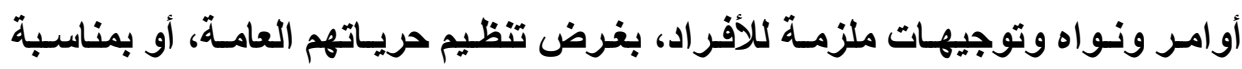

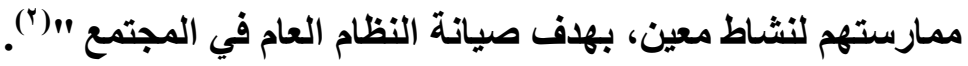
ويعرّف الدكتور زين العابدين بركات النظام العام بأنه يعني:" المحافظة على

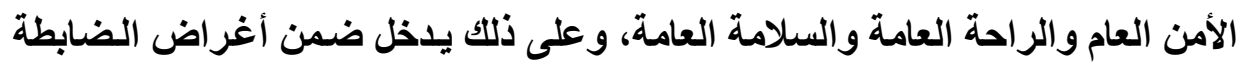
الإدارية كلما دعت الضرورة المحافظة على النظام العام "(").

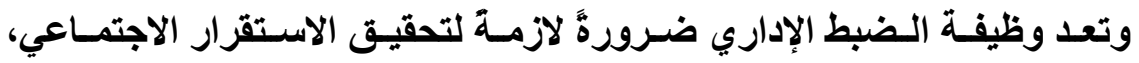

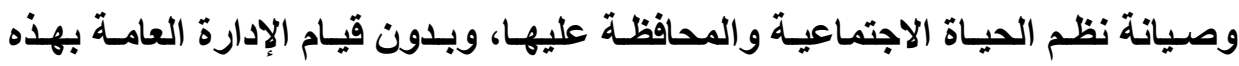

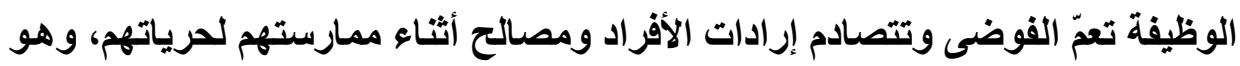

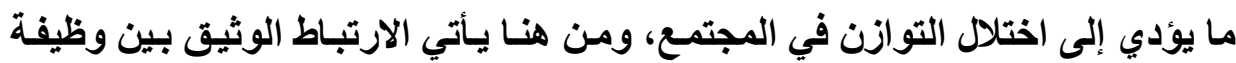

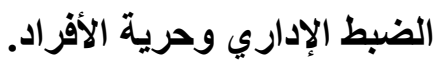

ولئن كان من واجب الإدارة العامـة أن تقوم بوظيفة الضبط الإداري للمحافظة

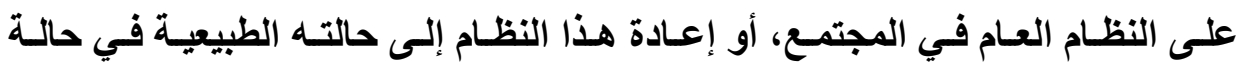
(1) د. سليمان الطماوي: الوجيز في القاتون الإداري (دراسة مقارنة)، القاهرة، دار الفكر العربي، . $0 \vee \varepsilon$ ص $19 \vee 9$ (ץ) د. طعيمة الجرف: القانون الإداري والمبادئ العامة في تنظيم ونثاط السلطات الإدارية، القاهرة،

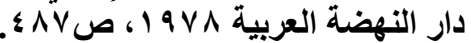

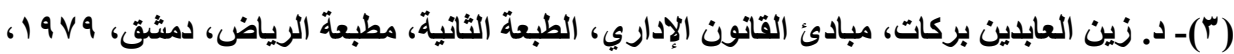

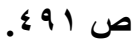


اضطر ابه أو اختلاله، أي وقاية النظام العام من الاضطراب والفوضس، والمحافظة على استقرار نظام المجتمع، فِإن على رجل الإدارة عندما يتخذ القرارات المتعلقة بالضبط الضطيط الإداري أن يستند إلى أسباب واقعية وقانونية سليمة.

ولما كان القضاء هو الحارس لحقوق وحريات الأفراد، لذلك فإنه ينهض بواجب

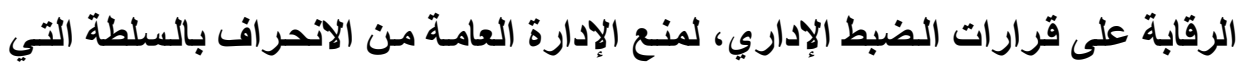

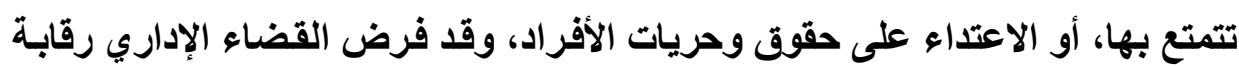

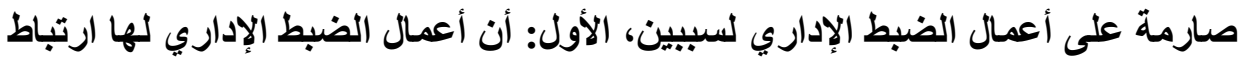

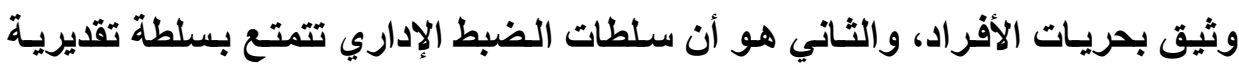

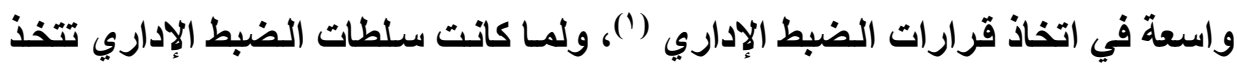

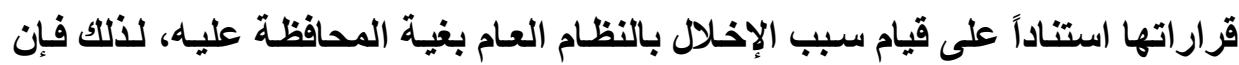

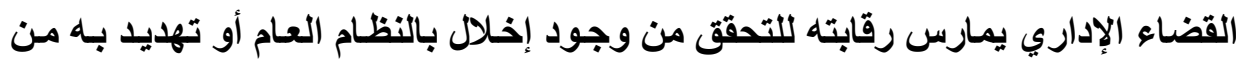
الناحية الواقعية، فهو يتأكد من صحة الوجود المـادي للوقائع التي تستند إليها الإدارة العامة، ويقوم بفص سلامة التكييف القانوني لها، ويفحص مدى التناسب بين الخطر الذي يهدد النظام العام وبين إجراعات الضبط التي اتخذتها الإدارة(؟). وسيحاول الباحث تسليط الـضوء على السبب في قرارات الضبط الإداريـة والرقابة القضائية عليه من خلال ما يلي: المبحث الأول: ماهية السبب في قرارات الضبط الإداري. المبحث الثاني: نطاق الرقابة القضائية على عنصر السبب في قرارات الضبط الإداري.

( (1)- عمر بوقريط، ومحمد زعداوي، الرقابة القضائية على تدابير الضبط الإداري، رسـالة ماجستير،

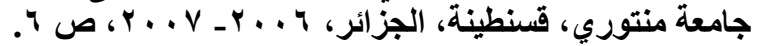

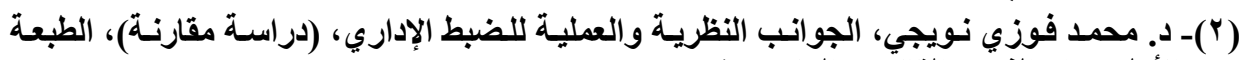

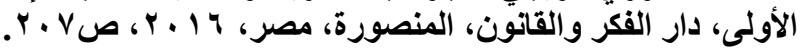




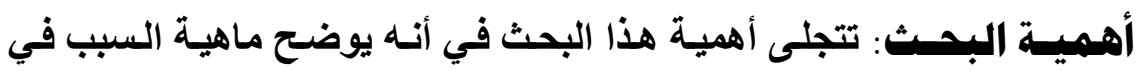

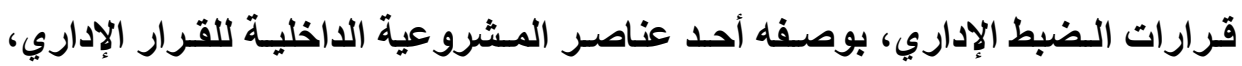

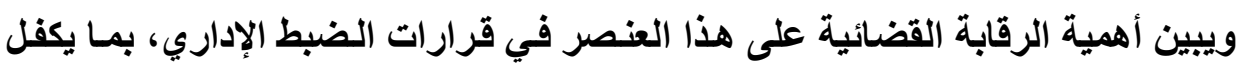

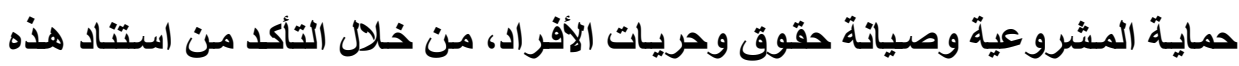

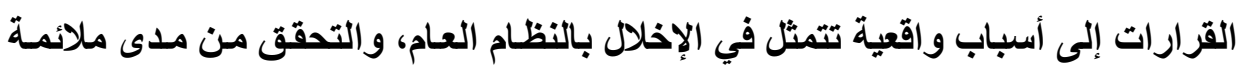
هذه القرارات التي اتخذتها الإدارة مع الوقائع.

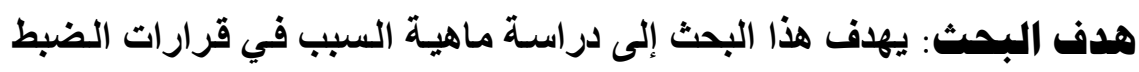

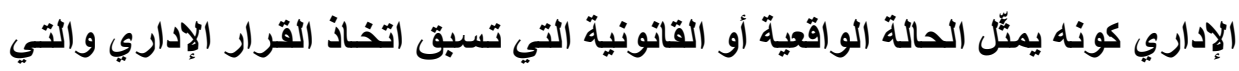

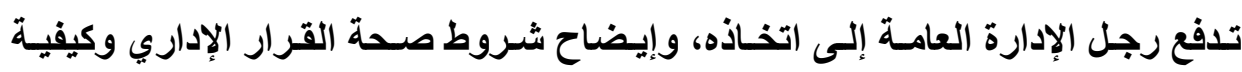

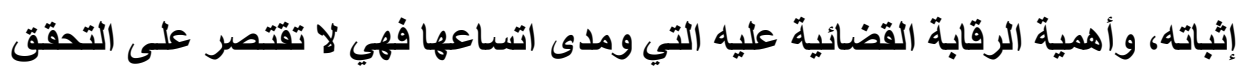

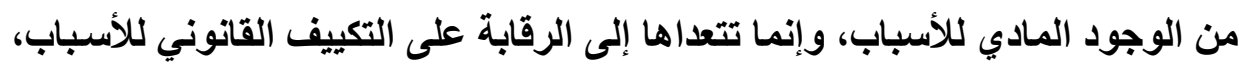

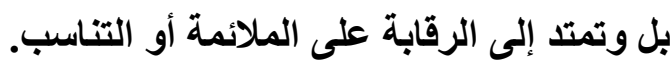

هشكلة البحث: رغم أهمية قرارات الضبط الإداري في مواجهة حالات الإنهات الإخلال

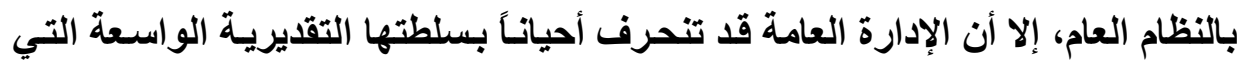

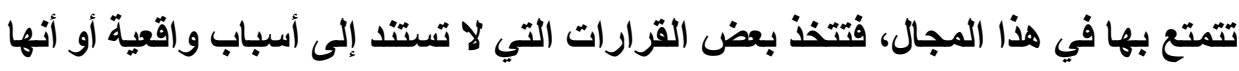

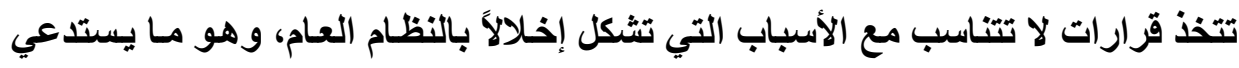

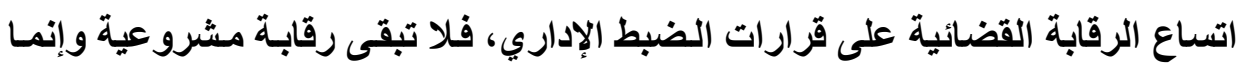

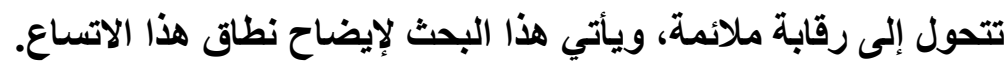

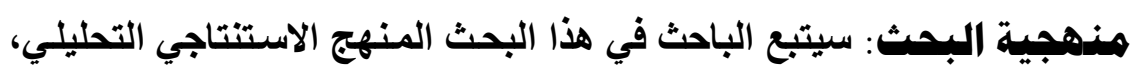

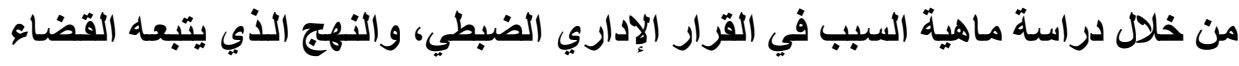
الإداري في الرقابة على عنصر السبب في قرارات الضبط الإداري الضبط واري. 


\section{المبحث الأول \\ ماهية السبب في قرارات الضبط الإداري}

يمثّل السبب الحالة الواقعية أو القانونية التي تسبق اتخاذ القرار الإداري والتي تدفع رجل الإدارة إلى اتخاذه، فعلى سبيل المثال حدوث اضطر ابات في الأمن العام تمثّل الحالة الواقعية التي تدفع الإدارة العامـة إلى اتخـاذ الإجراءات الضيطة للمحافظة على إنى الأمن العام، والنظام العام، وتقايم أحد الموظفين لاستقالته يمثل الحالة القانونية التي تدفع الإدارة إلى اتخاذ قرار بقبولهام' (')

ويقصد بأسباب قرار الضبط الإداري الوقائع الدافعة إلى اتخـاذه، ومدى جديثها وتهديدها للنظام العام، فيجب أن تكون هناك أسباب حقيقية جدية واقعية تهدد بـالإخلال بالنظام العام وتبرر تلخل الإدارة لاتخاذ إجراء ضبطي (؟). فالسبب عبارة عن إشارة لرجل الإدارة، تبين لله أنه لا يوجد ما يمنعه من اتخاذ القرار، وأنه يجب عليه أن يباشر سلطاته إذا مـا توافرت الشروط الأخرى، ولئن كـان السبب لا يتوقف على إرادة متخذ القرار، وهو يسبق اتخاذه، فِان ذلك لا يكفي لإبعاد كل

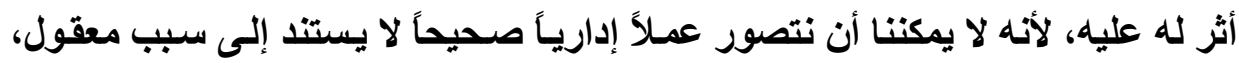
ويفترض في كل قرار إداري، حتى ولو خلا من ذكر أسبابه أن يستند إلى دواع للدى الإدارة التي اتخذته، وإلا كان القرار باطلاً لفقدانه ركناً أساسياً هو سبب وجودئ إنه ومبرر

( (1)- د. أنيس فوزي عبد المجيد، السبب في القرار الإداري بين النظرية و التطبيق ـ دراسة مقارنة بين الإني

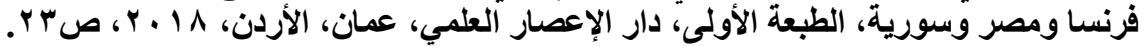

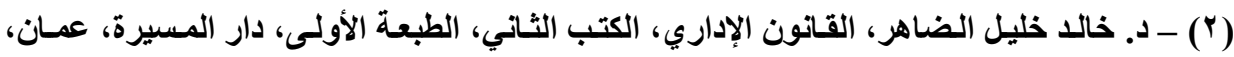
.9. (199V 


$$
\text { ما يلي: }
$$

لقد وجدت عدة تعاريف لسبب القرار الإداري، سواء من جانب الفقهاء أم من جاتب القضاء الإداري، وسيحاول الباحث ذكر هذه التعاريف من خلال ما يلي: الفرع الأول: التعريف الفقهي:

اهتم الفقه في فرنسا بتعريف سبب القرار الإداري، حيث عرف الفقيـه موريس

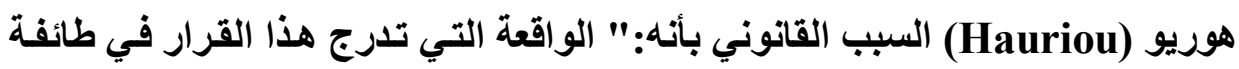

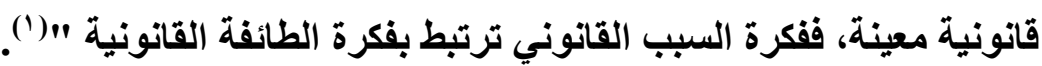

في حين عرّف فيدل Vedel السبب بأنـه:" حالـة موضوعية واقعية أو قانونية

تعتبر أسساس القرار "(`)

(1)- Hauriou (M), Précis de droit administratif et de droit public, 12, édit, Paris, 1933, p25.

" La cause juridique est le fait que cette décision est incorporée dans une communauté juridique spécifique. L'idée de la raison juridique est liée à l'idée de la communauté juridique ".

(2)- Vedel (G), Essai sur la notion de cause en droit administratife, Thèse, University de Toulouse, Facultè de droit, 1934, p360.

$=$ 
وعرفه بونـارد Bonnard بأنها:" عبارة عن حالة معينة أو عمل قـانوني أو

مادي يوحي بالقرار ويثكل سبب وجوده "(')

كما عرَّفه ديلوبادير Delubadère بأنه:" الو اقعة الموضوعية السابقة على الفي

القرار والخارجة عنه ويكون وجودها هو الذي دفع مصدر القرار إلى إصداره والقيام

ومن الفقه العربي عرَّف الدكتور سليمان الطماوي السبب بأنها:" حالة واقعية

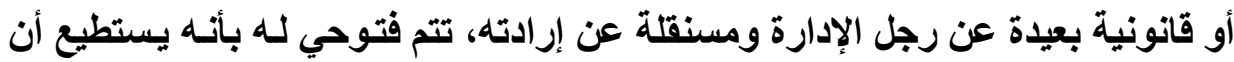

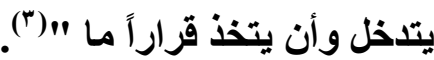

كما عرَّفه الدكتور محمد رفعت عبد الوهـاب بأنها:" حالـة واقعية (ماديـة) أو

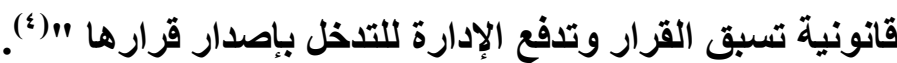

وعرَّفه الدكتور ماجد راغب الحلو بأنه:" الحالة الواقعية أو القانونية التي تدفع

رجل الإدارة إلى اتخاذ القرار "(•)

" La cause en est un cas objectif factuel ou juridique qui est à la base de la décision".

(1)-Bonnard (R), Précis de droit public, 6 édit , Paris, 1944, p28.

(2)-Delubadère (A.), Traitè èlèmentaire de administratife, 3, édit, L.G.D.J T.1- 1967- p483.

" La cause en est le bien-fondé objectif avant et en dehors de la décision, et son existence est ce qui a incité la source de la décision à émettre et à le faire".

(T)- د. سليمان محمد الطماوي، النظرية العامة للقرارات الإدارية، الطبعة السادسة، دار الفكر العربي،

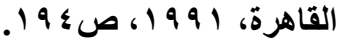

( ) - د. ماجد رفعت عبد الو هاب، القضاء الإداري، الكتاب الثاني، الطبعة الأولى، منشورات الحلبي

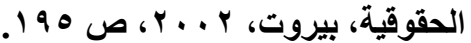

(•) د. ماجد راغب العلو، القانون الإداري، الطبعة الأولى دار المطبوعات الجامعية، الإسكندرية، .01. 1991 
وعرَّقهـ الدكتور محمد فؤاد مهنـا بأنـه:" الحالـة الواقعيـة (الوقائع والظروف

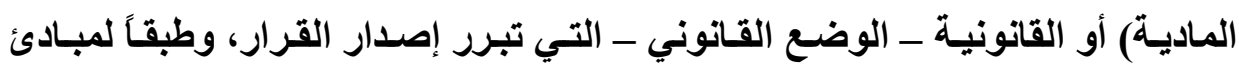

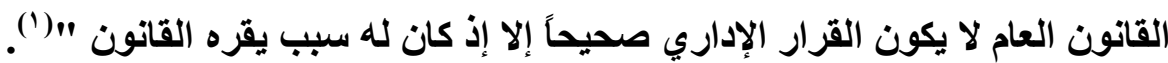
نلاحظ من خلال التعاريف السابقة أن السبب في القرار الإداري إمـا أن يكون

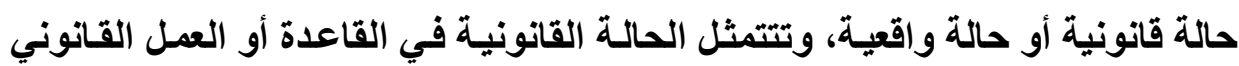
السابق الذي تستند إليه الإدارة في إصدار قرارها، وقد تثنترط هذه القاعدة قيام حسالات معينة لإصدار القرار وقد لا تشترط، وينبغي أن تكون الحالة القانونية موجودة الإدة دائمساً

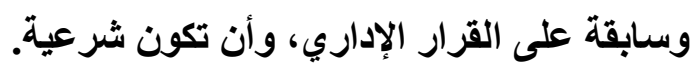

\section{ثانيًاً- التعريف القضائي:}

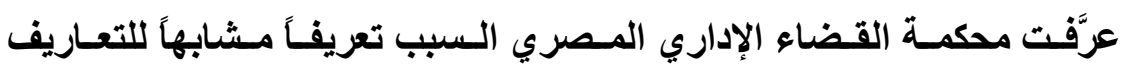

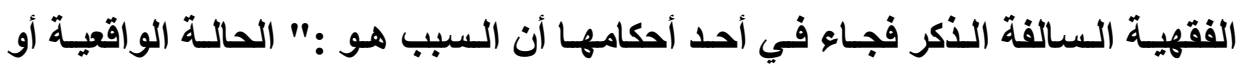
القانونية التي تسوّغ تلخل رجل الإدارة بسلطته الملزمة فيتجه في قراره لإحداث مركز

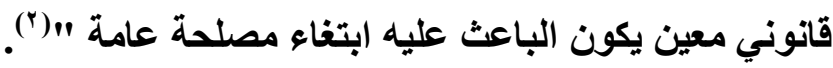
وهو ما أكَّته المحكمة الإدارية العليا المصرية منذ نشأتها، ومن أوائل أحكامها

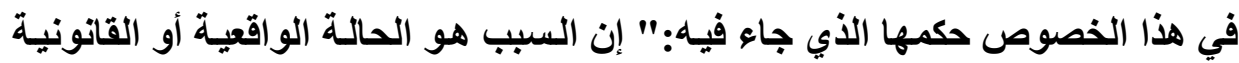
التي تسوغ تدخل الإدارة لإصدار القرار لإحداث مركز قانوني معين يكون الباعث عليه

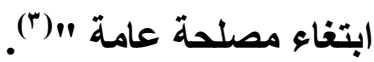

(1) - د. محمد فؤاد مهنا، القانون الإداري العربي في ظل النظام الاشتراكي الديموقراطي التعاوني،

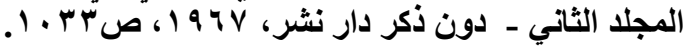

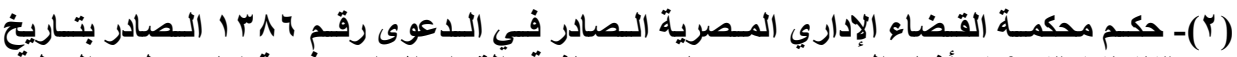

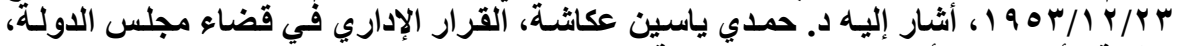

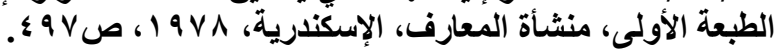

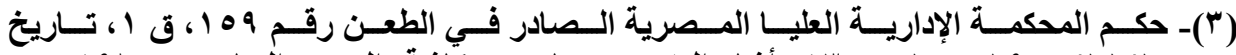
ه 
وقضت في حكم آخر:" هذا القرار شأنه شأن سائر القرارات الإدارية، يجب أن يقوم على أسباب تبرره صدقاً وحقاً في الواقع وفي القانون كركن من أركان انعقاده

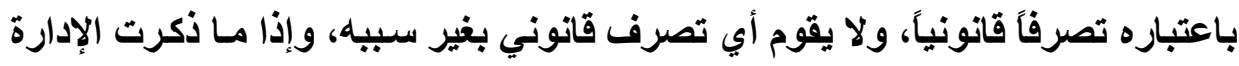

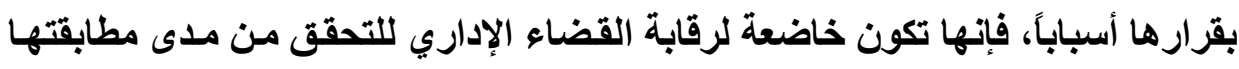

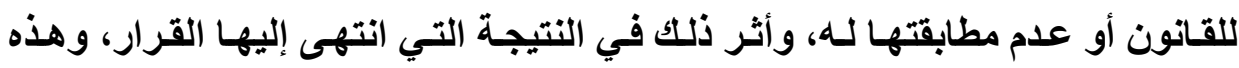

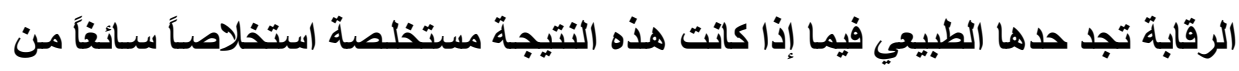

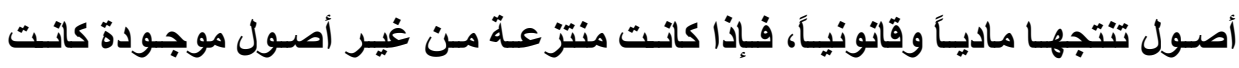

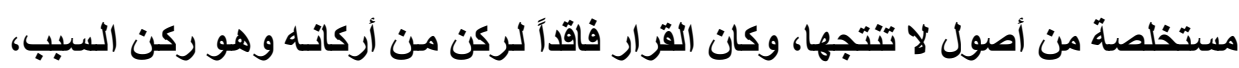

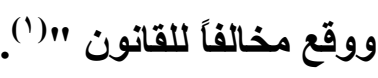
وخلاصة القول أن السمة الغالبة على السبب في القرار الإداري هي أنه عنصر موضوعي، فهو يجب أن يبقى خارج متخذ القرار، وهو ليس عنصراً شخصياً أو نفسياً

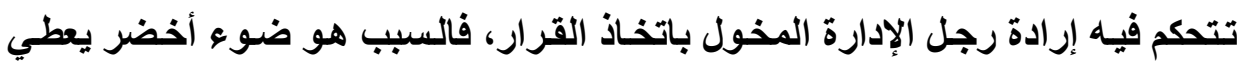
رجل الإدارة الرخصة في أن يمارس سلطاته، والسبب يظهر بشكل حالة قانونيـة، وبين

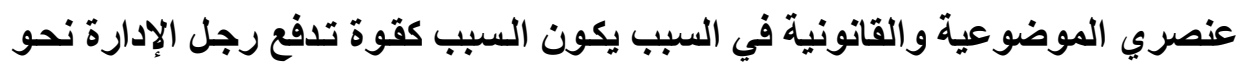
التفكير باتخاذ القرار، بما يلائم ظروف ومقتضيات العمل الإداري والمرفق العام. ولا بل من الإشارة أخيراً إلى أن السبب كركن من أركان القرار الإداري يختلف عن التسبيب، حيث عرَّف الفقيه الفرنسي فيدل Vedel تسبيب القرار الإنداري بأنسانه:"

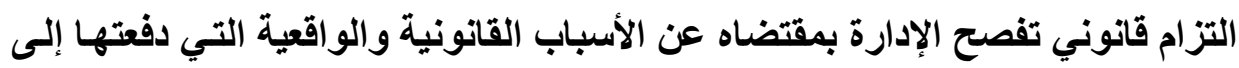

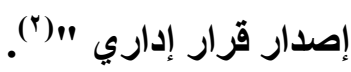

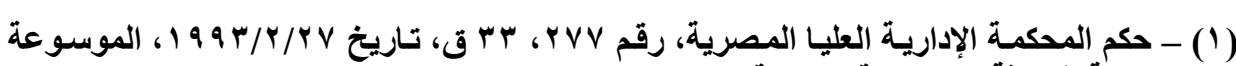

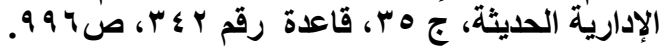

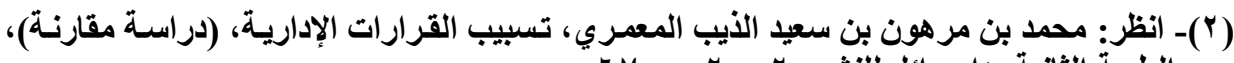

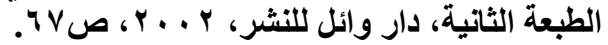




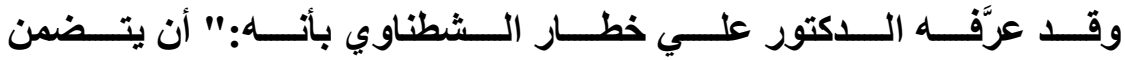

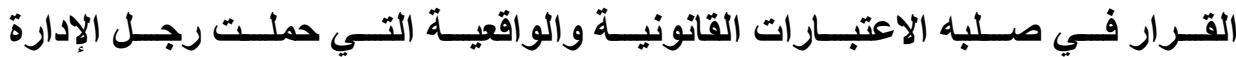

$$
\text { على إصداره "(1) (1) (1) }
$$

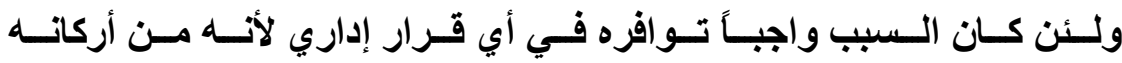

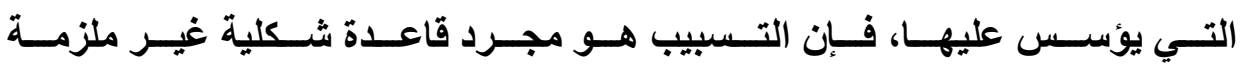

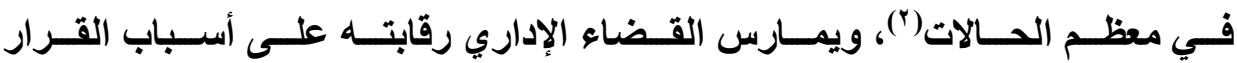
الإداري باعتبـاره ركنـاً مستقلاً وقائمساً بذاته، ويشكّل أحد أوجـه الإلفـاء، في حين لا

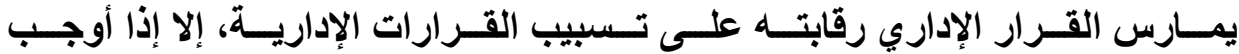
القـانون تعليلها وتسبيبها صراحة أو فرضـها القضاء، كمـا أن تسبيب القرار يتندرج ضمن عيب الثكل (") - (ب)

\section{الاطلب الثاني \\ شروط صحة السبب}

يشترط الفقه والقضاء عدة شروط يجب توافرها في الأسباب التي تستتد إليها الإدارة في إصدار قرارها حتى يغدو السبب صحيحاً والقرار الإداري صحيحاً هو الأخر، وتنطبق هذه الشروط على قرارات الضبط الإداري شأنها في ذلك شـأن سـائر القرارات الإدارية الأخرى، وهذه الشروط هي:

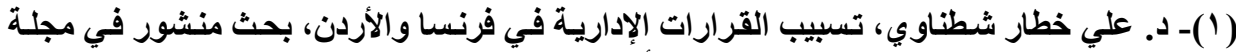

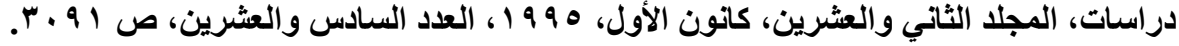

(2)-Guillaume Bhanc: - "Motifs et motivation des decisions administratives" - R.A. 1998 - p. 496.

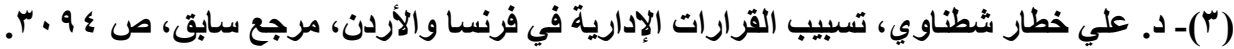




\section{أولاً أن يكون السبب قائهًا وهوجوداً عند إصدار القرار الإداري:}

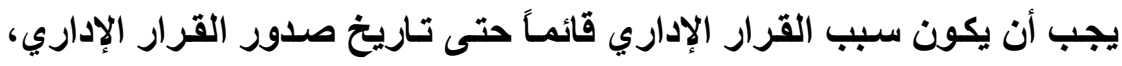

فإذا زالت الأسباب التي تدفع الإدارة إلى إصدار قرار معين، وصدر القرار بـالرغم من الإن

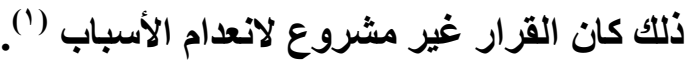

وقد أكَّدات المحكمـة الإداريـة العليـا المـصرية هذا الشرط حيث جـاء في أحـا

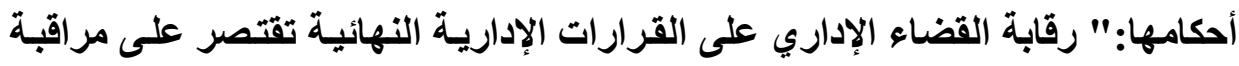

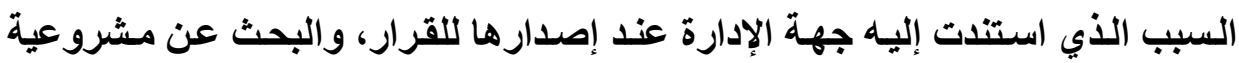

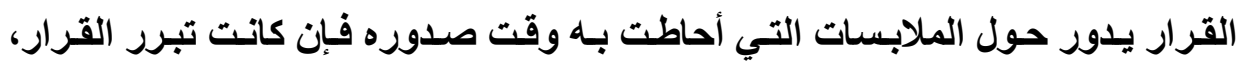

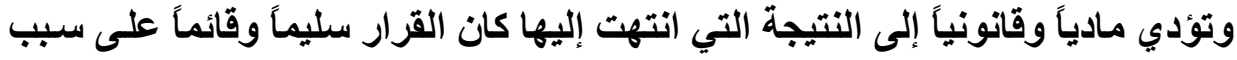

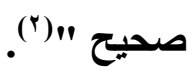

ولا يعتد بالسبب الذي لـم يكن موجوداً لحظة صدور القرار الإداري، ولكنـه

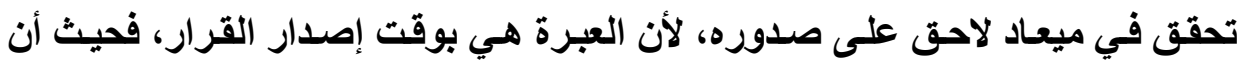

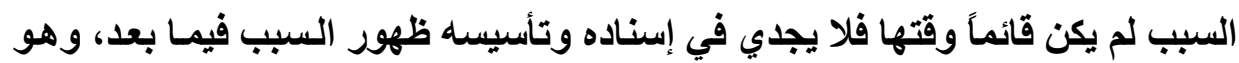

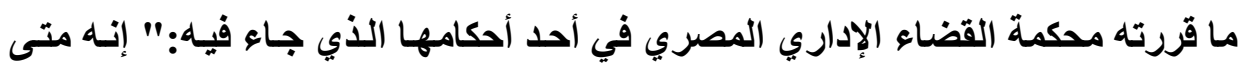
بني القرار الإداري على سبب معين قام عليه واستمد كيانه من سند قانوني أفصح عنده فئه

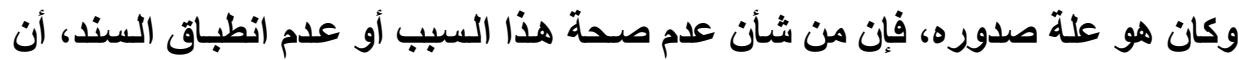

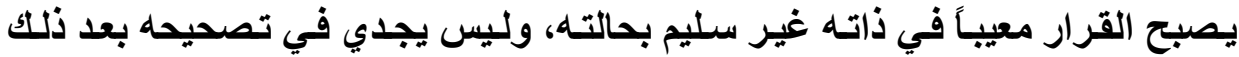

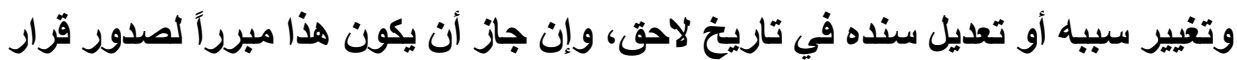

جديد على الوجه الصحيح "(").

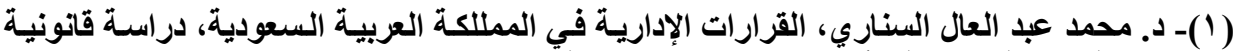

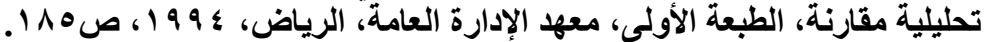

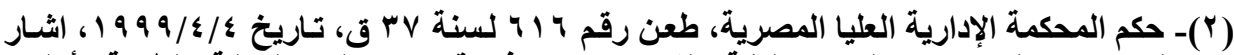

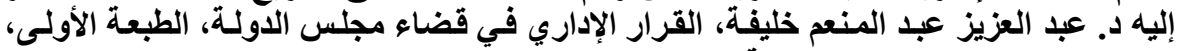

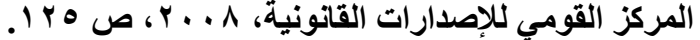

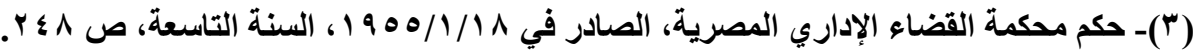




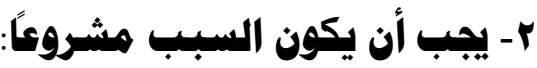

إن صدور القرار الإداري استناداً إلى سبب موجود وقائم في تـاريخ صدوره لا يكفي لصحته، بل يجب أن يكون هذا السبب مشروعاً أي مطابقاً للقانون.

ونميز هنا بين حالة السلطة المقيدة للإدارة - حيث يحدد المشرع أسباباً معينة

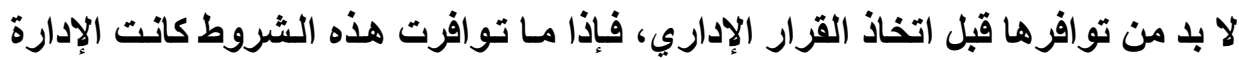

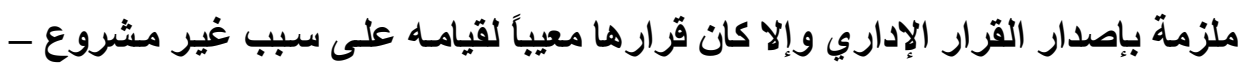

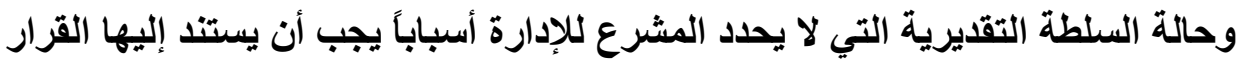

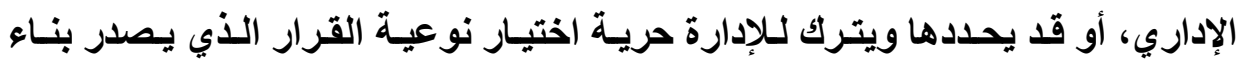

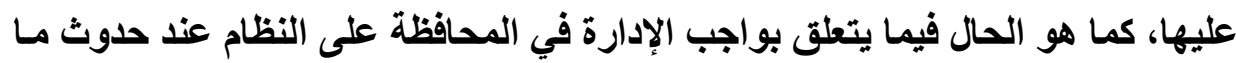

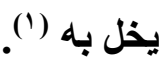

ويشكل هذا الشرط استثناعً من الأصل العام، الذي بموجبه تتمتع الإدارة بحريـة

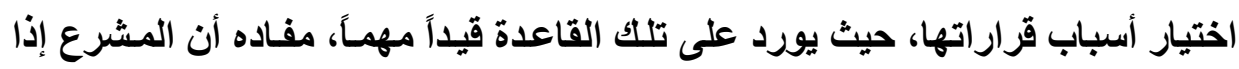

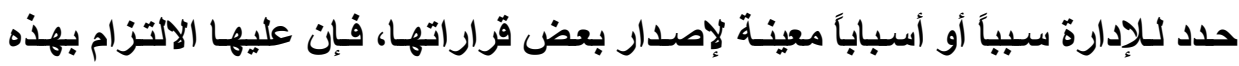

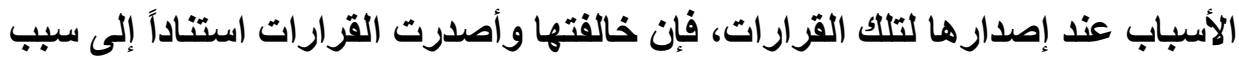

أجنبي عنها كان قرارها في هذا الشأن باطلاً لقيامه على سبب غير مشروع (). فقررات الضبط الإداري التي تستتد إلى وقائع لا تمت إلى النظام العام بعناصره

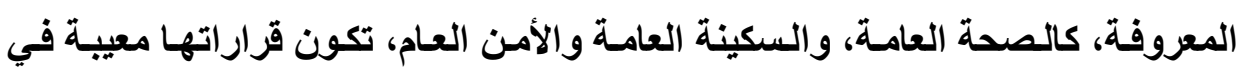

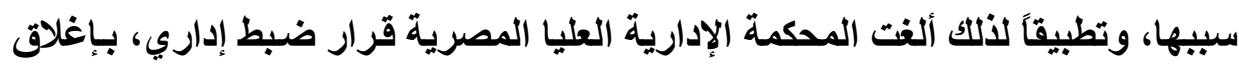
سوق يوم الإثنين من كل أسبوع حيث اتضح لها أن سبب الإغلاق هو إعطاء الفرصة الإله

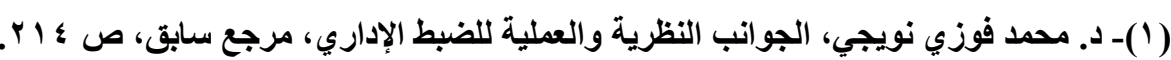

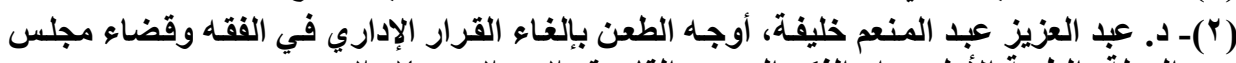

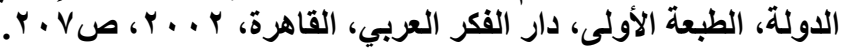


لرواج سوق عمومي، وهو سبب لا علاقة له بالمحافظة على النظام العام، وهو السبب

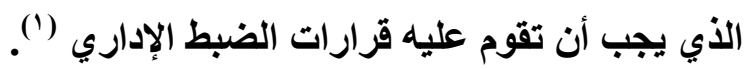

والعبرة في تقدير مدى مشروعية السبب الذي بنـي عليه القرار، يكون بـالنظر إلى السبب الحقيقي الأي صدر استناداً إليه القرار المطعون فيه.

ولا يقتصر تطلب مشروعية القرار الإداري على الحالة التي تكون فيها سلطة

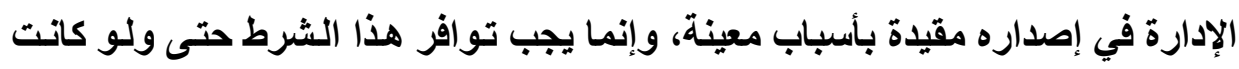

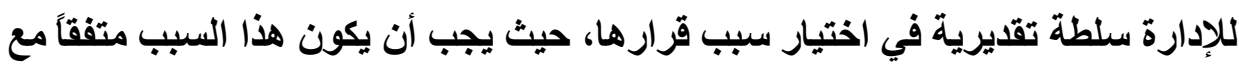
أحكام الاستور والقانون بمعناه الواسع.

\section{r- يجب أن يكون السبب همددأ بوقائع يقوم عليها:}

يجب أن يكون سبب القرار الإداري محدداً وواضـاً، فـلا يكفي السبب العـام

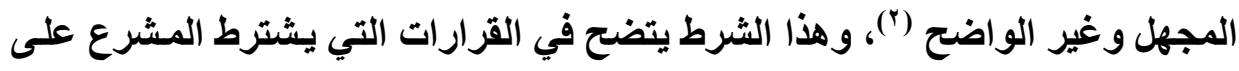
الإدارة ذكر أسباب إصدار قراراتها، بالإضافة إلى القرارات التي تصدر ها مسبية دون أن يلزمها المشرع بذلك.

وفي التحديد الواضح لسبب القرار الإداري، تمكين لصاحب الشأن من أن يحدد

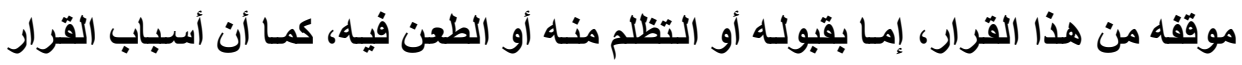
الإداري المحددة التي لا يشوبها لبس أو غموض الخالية من التعميم أو التجهيل تمكّن التهن

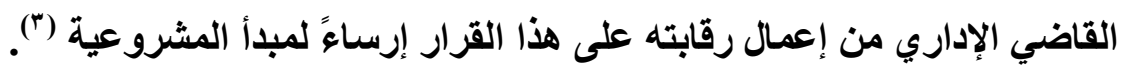

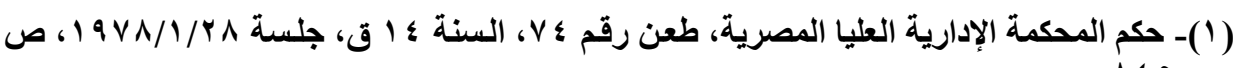
. $\wedge \leqslant 0$

(ץ) - د. محمد عبد العال السناري، مجلس الدولة والرقابة القضائية على أعمال الإدارة في جمهورية

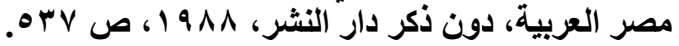

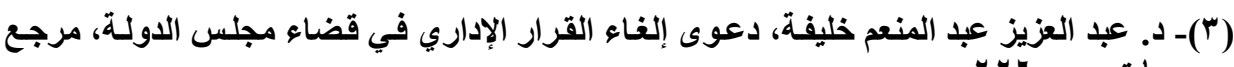

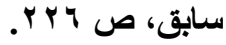




\section{المطاب الثالث \\ إثبات سبب القرار الإداري}

الأصل أن الإدارة العامة غير ملزمة بالإفصاح عن أسباب قراراتها ما لم يلزمها

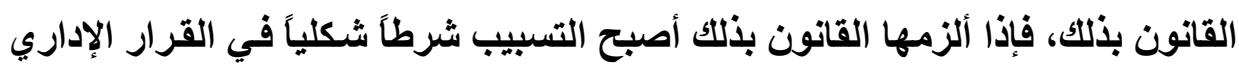
يترتب على تخلفه بطلان القرار الإداري (') ولا تثور مشكلة إثبات سبب القرار الإداري في حالة ذكر الإدارة العامـة لسبب

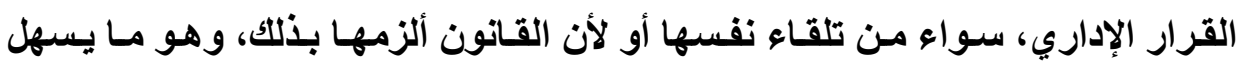

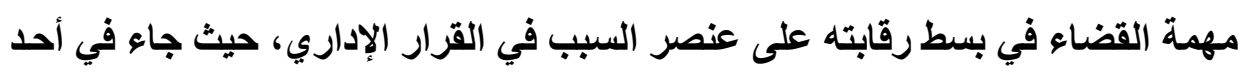

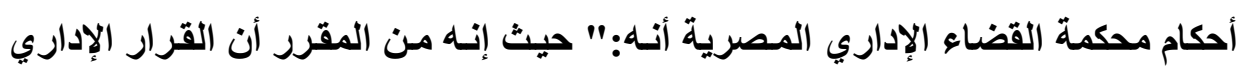

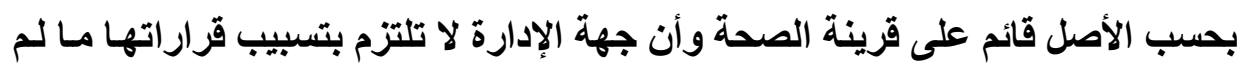

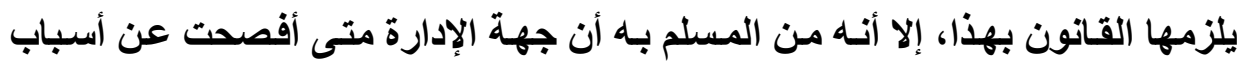

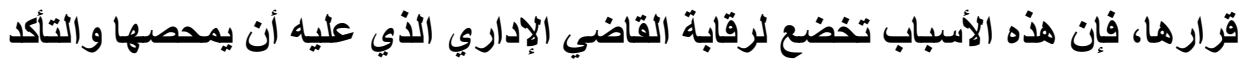

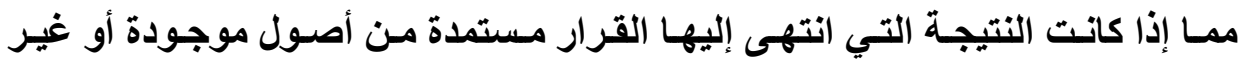

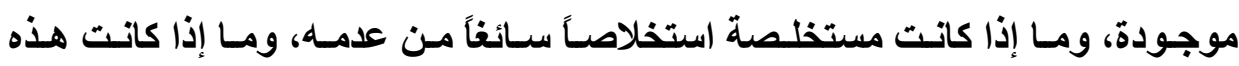

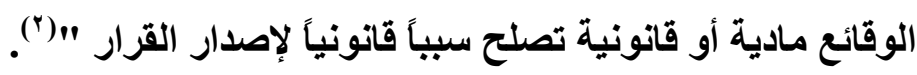
وكاتت المحكمة الإداريـة العليا المصرية قد قضت بأنسه:" يجب التفرقة بين

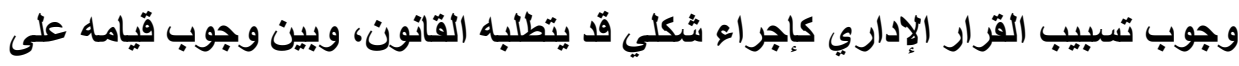

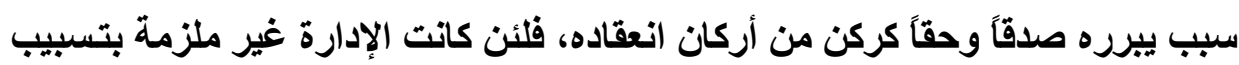

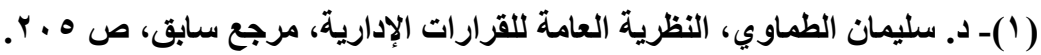

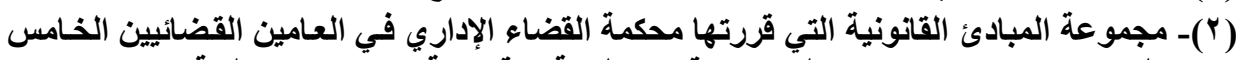

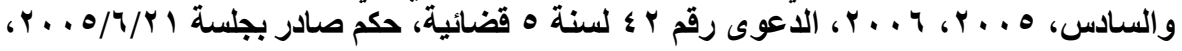


قراراتها إلا إذا أوجب القانون ذللك عليها، وعندئذ يتعين عليها تسبيب قرارهـا وإلا كـان

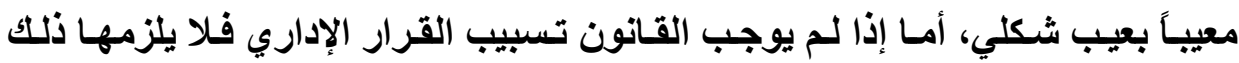
كإجر اء شكلي لصحته، بل ويحمل القرار على الصحة كما يفترض فيه ابتداءُ قيامه على

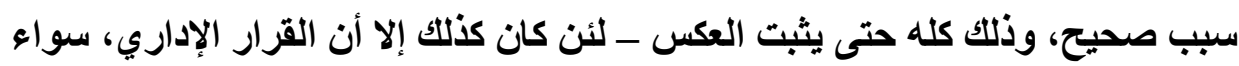
أكان لازماً تسبيبه كإجراء شكلي أم لم يكن هذا التسبيب لازماً، يجب أن يقوم على سبب لهن يبرره صدقاً وحقاً، أي في الواقع والقانون، وذلك كركن من أركان انعقاده، باعتبار القرار تصرفاً قانونياً، ولا يقوم أي تصرف قانوني بغير سبيه، والسبب في القرار الإداري هو حالة اقعية أو قانونية تحمل الإدارة على التدخل بقصد إحداث أثر قانوني هو محل القرار، ابتغاء وجه الصالح العام الذي هو غاية القرار "('". فإذا لـم تفصح الإدارة عن أسباب قرارهـا في الحسالات التي لا يلزمها القانون بذلك، فـإن القاضسي الإداري يستطيع إلزامها بـللك لبسط رقابته على القرار الإداري وعنصر السبب، وهذا ينبع من الدور الإيجابي الذي يلعبه القاضسي الإداري في تنظيم

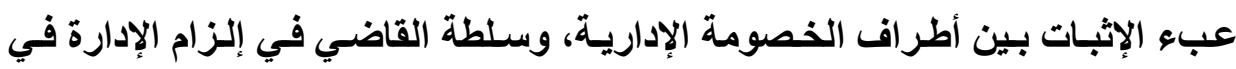

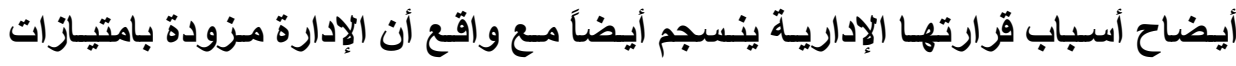

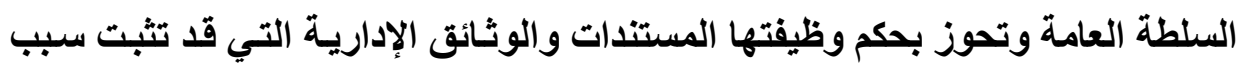

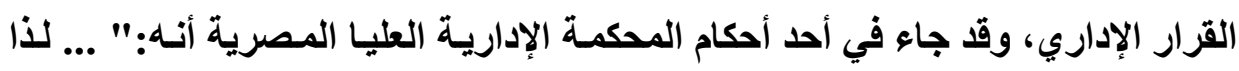
مسن المبـادئ المستقرة في المجـال الإداري أن الإدارة تلتـزم بتهـــيم ســائر الأوراق والمستندات المتعلقة بموضوع النزاع والمنتجة في إثباته إيجاباً و نفياً متى طلب منها

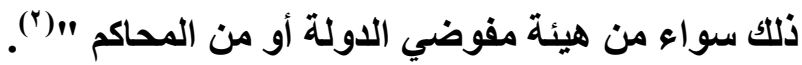

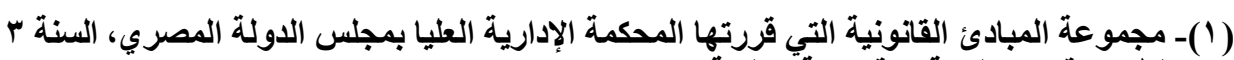

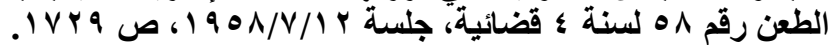

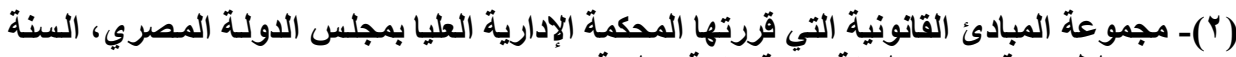

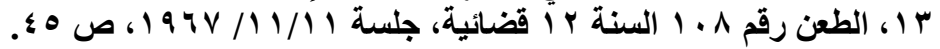


والحقيقة أنه يفترض صحة القرارات الإدارية، وتبقى قرينة الصحة قائمسة إلى الصى

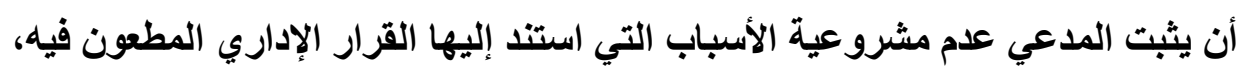

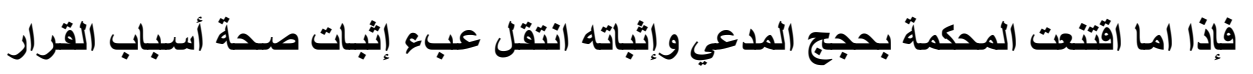

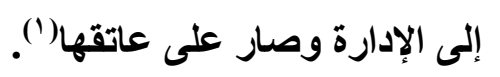




\section{المبحث الثاني \\ نطاق الرقابة القضائية على عنصر السبسب لهب في قرارات الضبط الإداري}

لا يخفى على أحد مدى خطورة وظيفة الضبط الإداري على حريـات الأفراد إذا

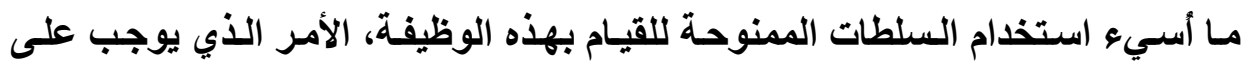
هيئات الضبط الإداري العمل على تحقيق التوازن بين متطلبـات المحافظة على النظام

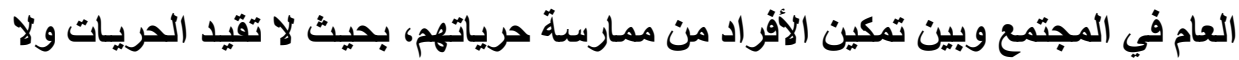

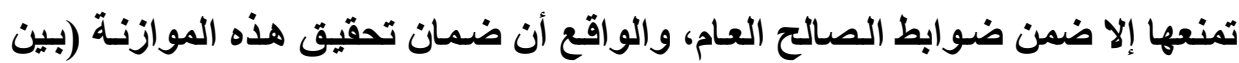

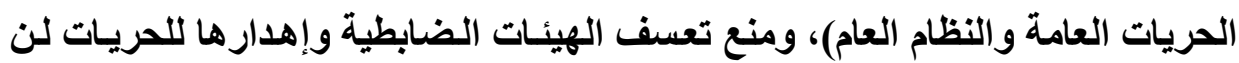
يكون فعالاً ومستقلاً بدون إمكانية مراجعة أعمالها بواسطة رقابة قضائية فعالة، تضمن وهن بقوة أحكامها التزام هيئات الضبط حدود سلطانها، وبذلك يمكن القول إن هنـاك حريـات مصانة دستورياً وقانونياً...

وتمثّل الرقابـة القضائية على قرارات الضبط الإداري ضمانة مهمـة وأساسية

لحماية الحريات العامة للمواطنين، فـالإدارة تمـارس نشاطها في مجال الضبط الإداري

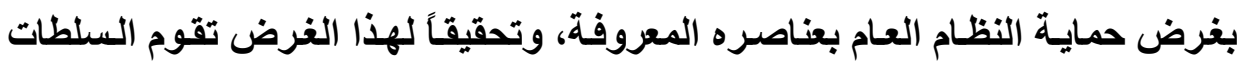

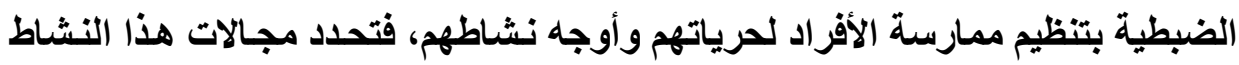
وتورد عليهم من القيود مـا تتطلبه المحافظة على النظام العام فمع التسليم بالأهمية

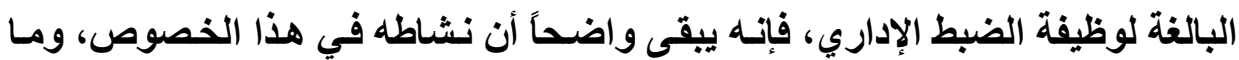

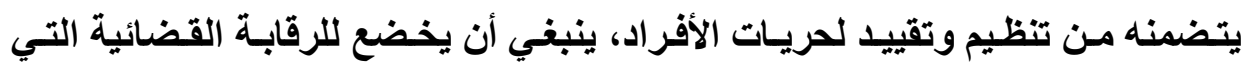

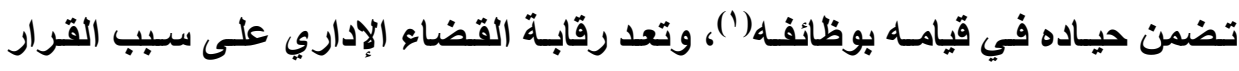


الإداري الضبطي من أهم الضمانات الأساسية لاحترام سلطات الضبط لمبدأ المشروعية في تصرفاتها.

وقد بسط القضاء الإداري في مصر رقابته على عيب السبب على خطى مجلس

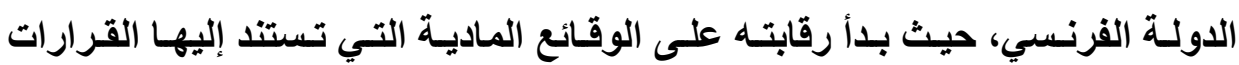

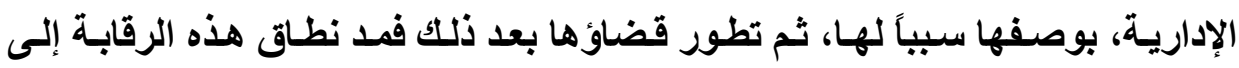

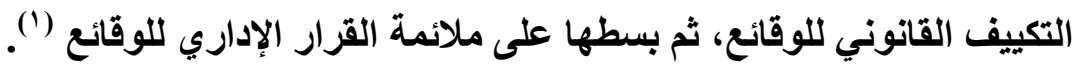
ويتحقى القضاء عند قيامه بالرقابة على إجراعات الضبط الإداري التي قامت بها الإدارة من مدى كون ظروف الحادث الواقعيـة تؤكّد أو تنفي خطر الإخـلال بالنظـام

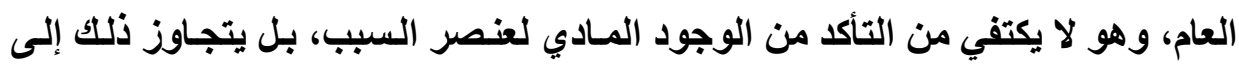
فصص سلامة التكييف القانوني الأي أسبغته سلطة الضبط الإداري على هذه الوقائع، وكذلك يقوم بفحص مدى التناسب بين شدة الإجراء الضبطي المتخذ وخطورة الوقائع

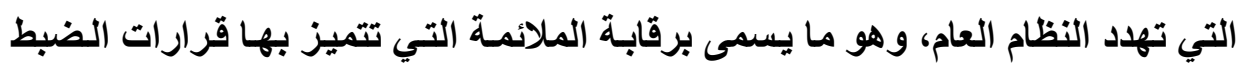

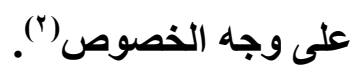
سيحاول الباحث شرح نطاق الرقابة القضائية على قرارات الضبط الإداري من

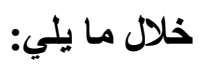
المطلب الأول: الرقابة على الوجود المادي للأسباب. المطلب الثاني: الرقابة على التكييف القانوني للأسباب. المطلب الثالث: الرقابة على الملائمة أو التناسب.

(1) - د. عبد الغتي بسيوني عبد الله، القانون الإداري، دراسة مقارنة لأسس ومبادئ القانون الإداري

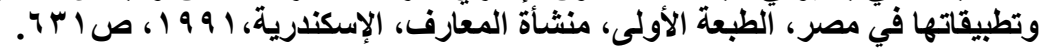

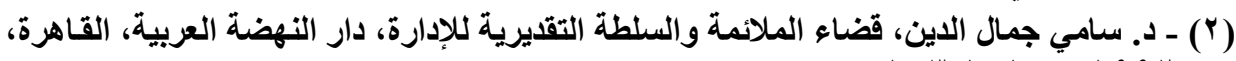

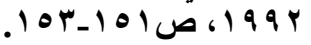




\section{المطلب الأول}

\section{الرقابة على الوجود المادي للأسباب}

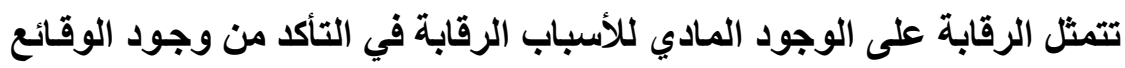

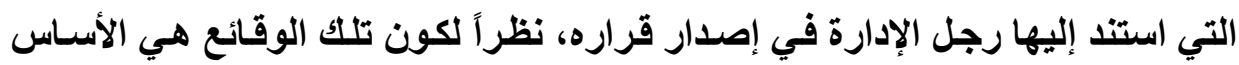

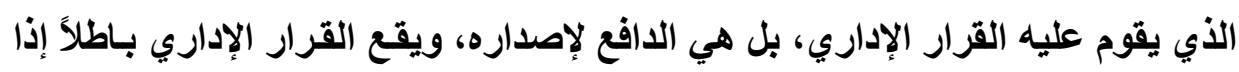
ما ثبت عدم صحة ما استندت إليه الإدارة في إصدار قرار الإدها من وقائع. وتقوم قرارات الضبط الإداري عـادة على وقـائع تشكّلّل إخـلالاً بالنظـام العسام

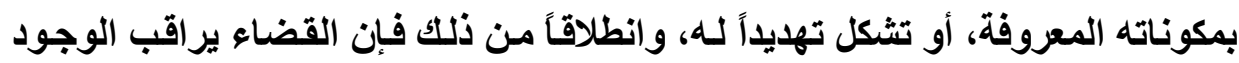

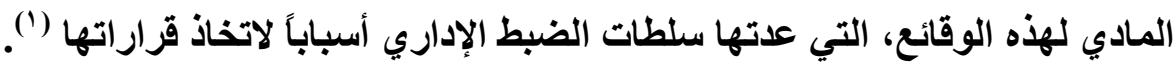

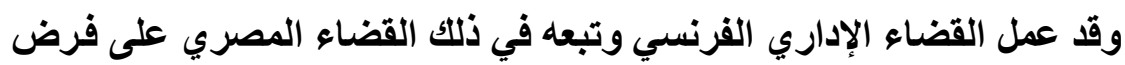

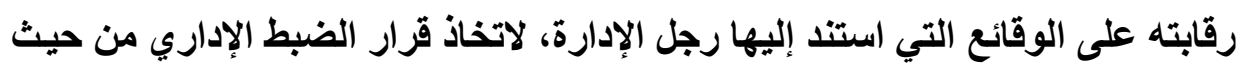

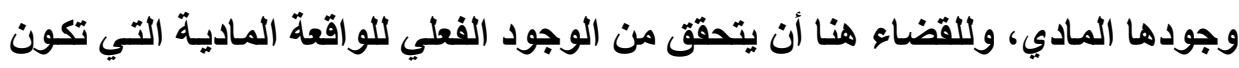

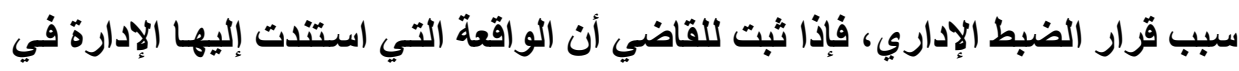

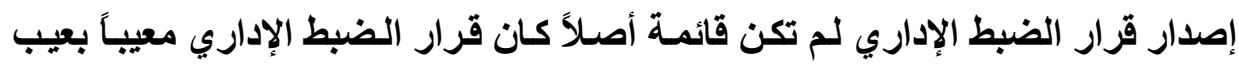

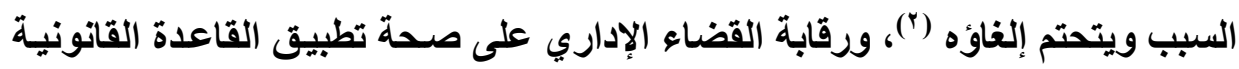

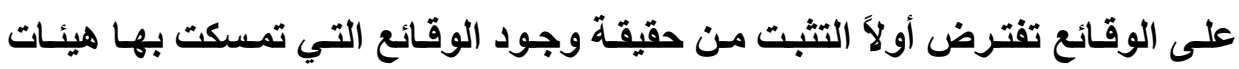

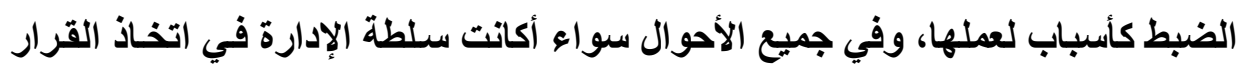

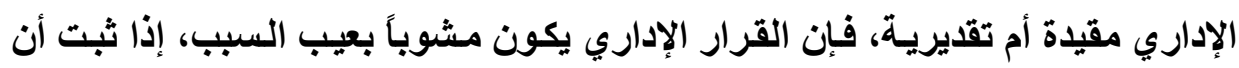

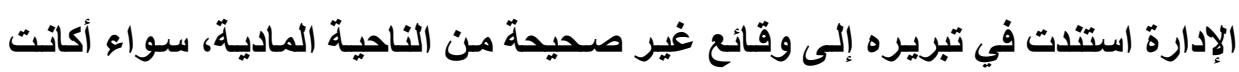

\footnotetext{
(1) ـ عمر بوقريط، ومحمد زعداوي، الرقابة القضائية على تدابير الضبط الإداري، مرجع سـابق، ص (Y) - د. محمد محمد بدران، رقابة القضاء الإداري على أعمال الإدارة، دار النشر للجامعات المصرية،

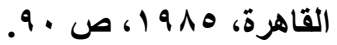


الإدارة حسنة النية، أي كانت تعتقد بقيام الوقائع التي تدعيها، أم كاتت سيئة النية وتعلم

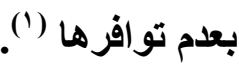

وقد كان مجلس الدولـة الفرنسي قد استثنى من الرقابـة على الوجود المـادي

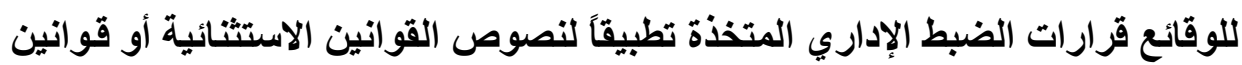

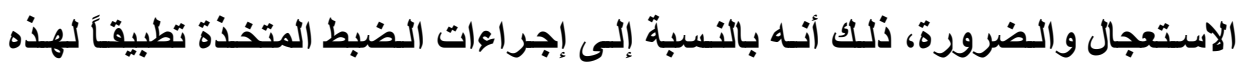
القوانين، النـي يطلق عليهـا بعض الفقهاء اصطلاح (إجراءات الضبط العليـا) كـان

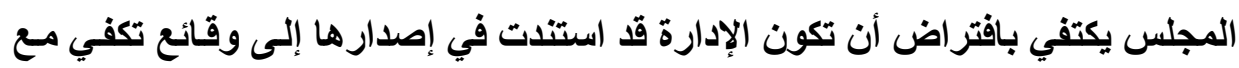

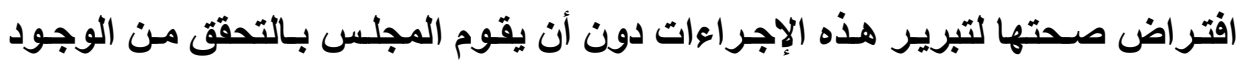
الفعلي لهذه الوقائع، وهذه هي حساتات إجراءات الضبط التي اتخذنتها الإدارة تطبيقاً

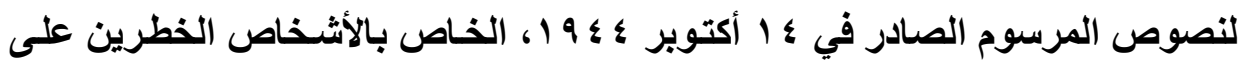

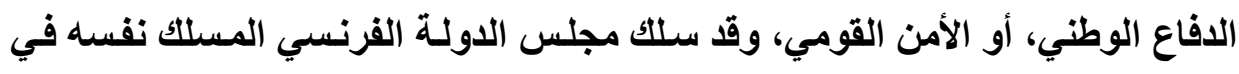

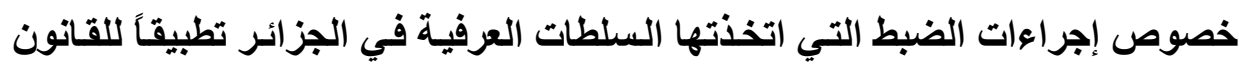

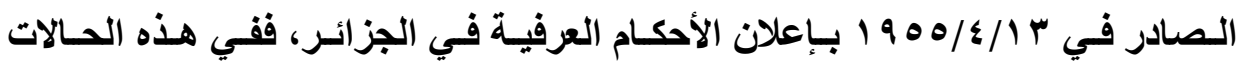

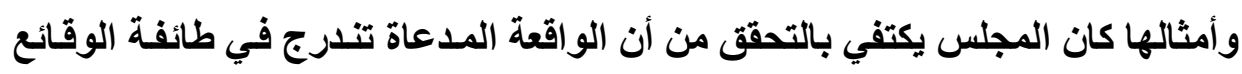

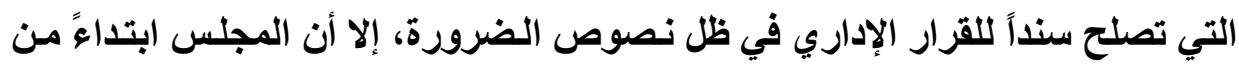

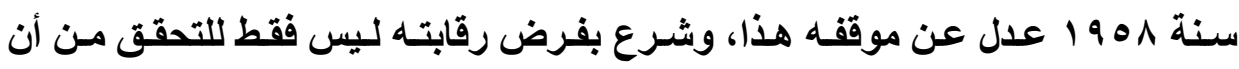

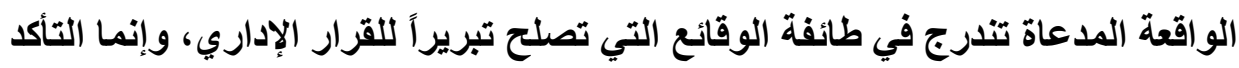

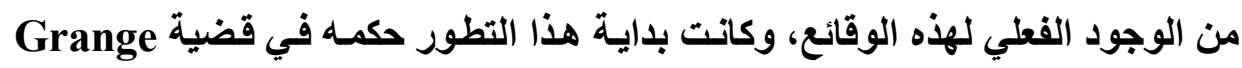

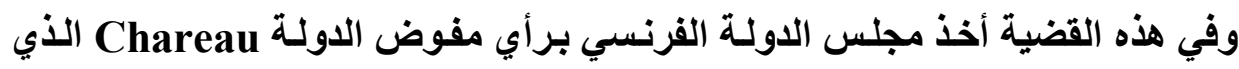

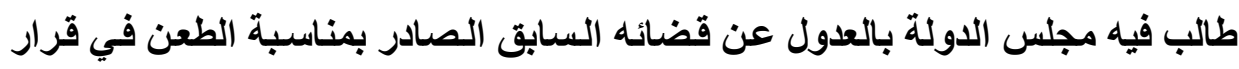

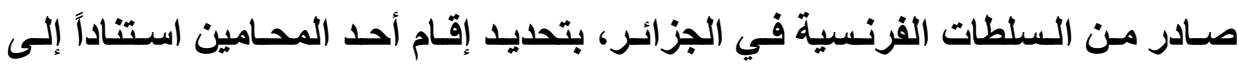

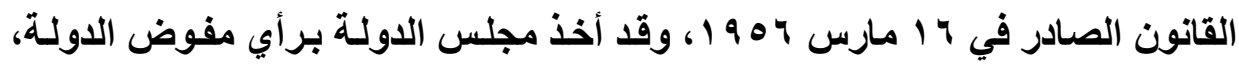

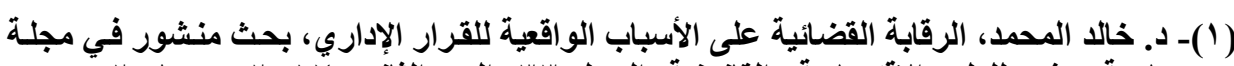

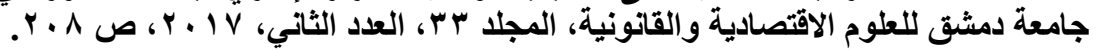


وقرر فرض رقابته لتتحقق من الوجود المادي لهذه الوقائع، وحكم بإلغـاء تحديد إقامـة

(') Grange السبيد (')

وقد أكَّد مفوضو الحكومة في فرنسا على أن التحقق من الوجود المادي للوقائع

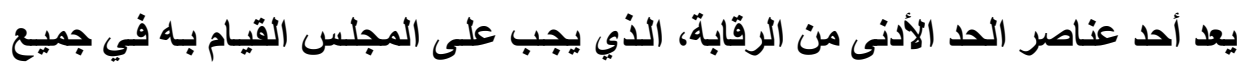
الحالات، وبخصوص جميع القرارات الإدارية، وابتداءً من الحكم المشار إليه أعلاه فقد الدابه

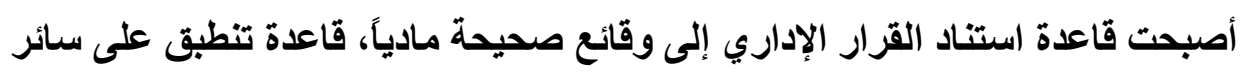
القرارات الإدارية وعلى رأسها قرارات الضبط الإداري، ولا يرد عليها أي استثناء (؟). إذاً يجب قانوناً لصحة القرار الإداري أن يقوم على وقائع صحيحة وثابتة، وإلا

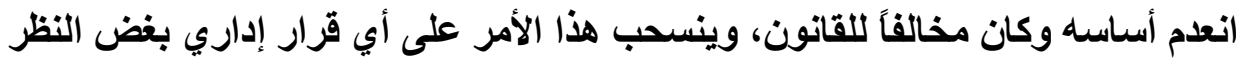
عن موضوعه باعتبار أن ذلك يعتبر الحد الأدنى من الرقابة على القرار الإداري. وقد أخذت المحكمة الإدارية العليا المصرية منذ إنشائها سنة هـو 190 ذات النهج

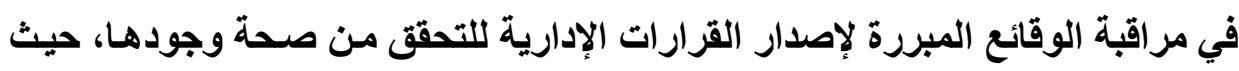

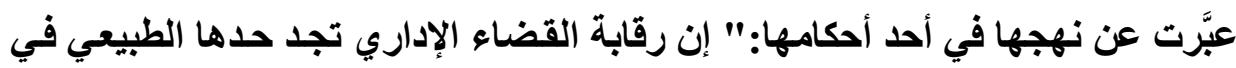
التحقق مما إذا كانت النتيجة التي انتهى إليها القرار مستمدة من أصول موجودة أو أو غير موجودة، وما إذا كاتت هذه النتيجة مستخلصة استخلاصاً سائغاً من أصول تنتجها

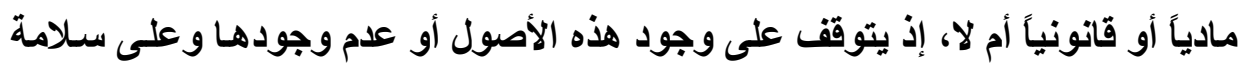

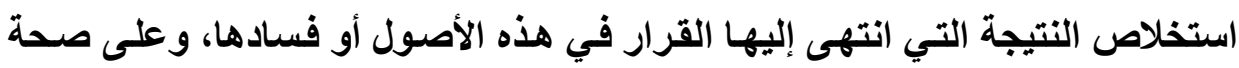

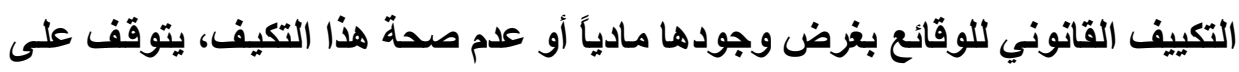

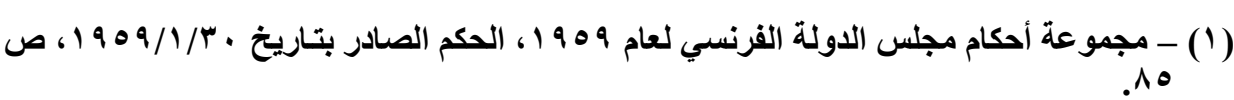
(Y) ( د. حسنين عبد العال محمد، الرقابة القضاية على قرارات الضبط الإداري، الطبعة الثانية، دار

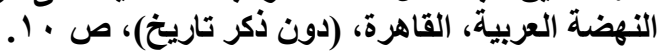


هذا كله قيـام أو عدم قيـام ركن السبب في القرار الإداري، ومطابقته أو عدم مطابقته

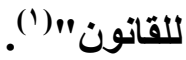

وقد أصدرت المحكمة بعد ذلك العديـ من الأحكام القضائية المتعلقة بقرارات الضبط الإداري تطبيقاً لهذه المبادئ التي حددتها في هذا الحكم، ولا سيما قرارات إبعاد

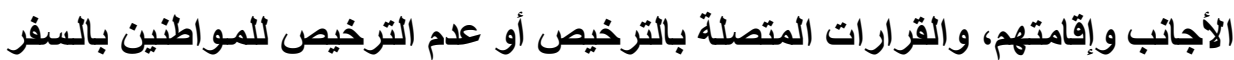

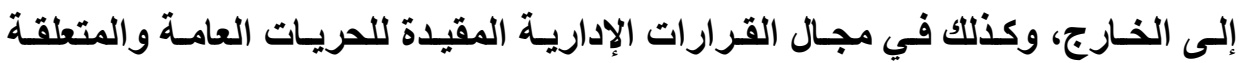
بالمحافظة على النظام العام والمستندة إلى مجرد شبهات قويـة دون أن تستلزم قيامها على وقائع محددة تبرر اتخاذها (r). وقد استقرت أحكام محكمة القضاء الإداري منذ نشأتها على ضرورة أن تقوم قرارات الضبط الإداري المتعلقة برفض الترخيص بسفر المواطنين للخارج على أسباب

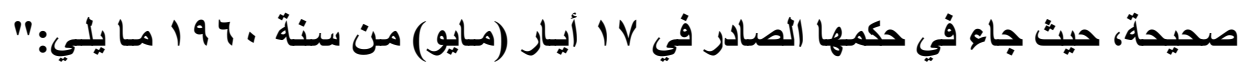
... سلطة الادارة في تقييد حريـة المواطنين في السفر مقيدة بقيام أسباب في طالب في فئه

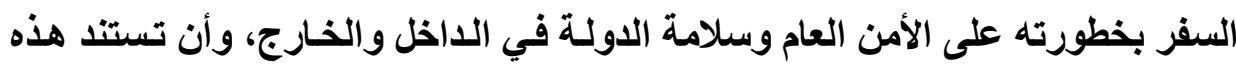
الأسباب طبقا لما استقر عليه قضاء تلكك المحكمة الى أصول ثابتة في الأوراق تؤيـها

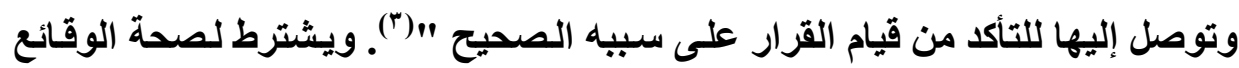

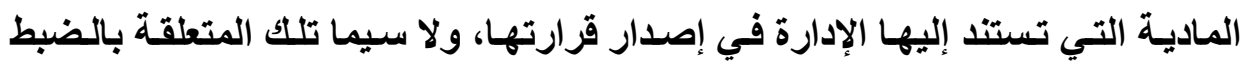
الإداري مجموعة من الثروط تتلخص بما يلي (؛):

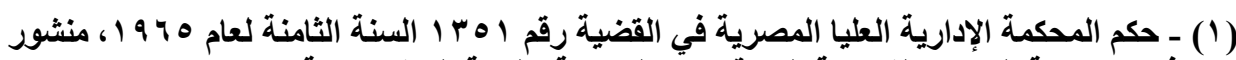

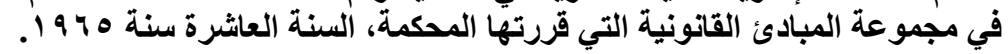

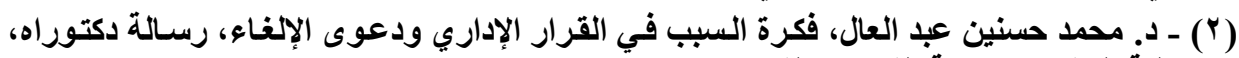

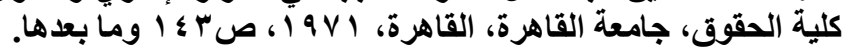

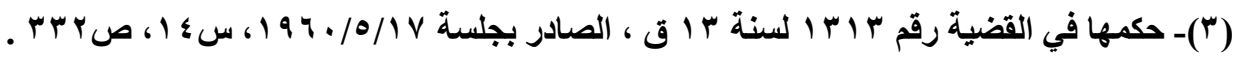

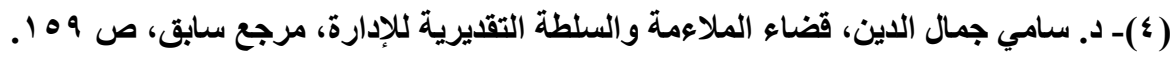


ا - أن تكون الوقائع محقةـة الوجود، وقائمـة مـن وقت طلب إصدارها إلى وقت

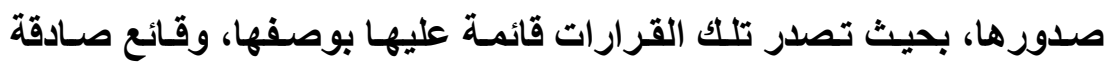

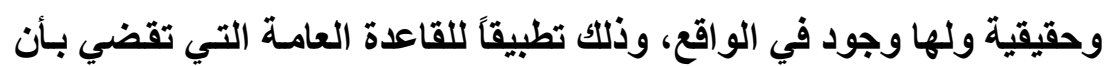
تاريخ صدور القرار هو الوقت الذي يتم الرجوع إليه لتقدير مشروعية هذا القرار، أو عدم مشروعينه. r ـ أن تكون الوقائع محددة، ولذلك فقد اتجه الفقه والقضاء في مصر وفرنسا إلى اعى

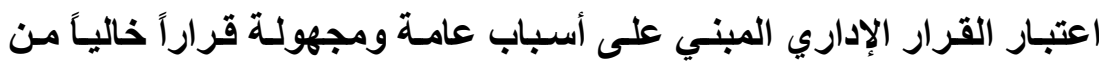

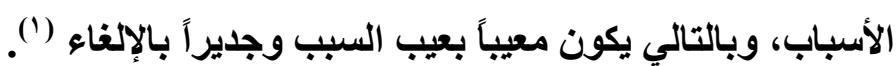
rـ أن تكون الأسباب المادية جدية ومشروعة، حيث جـاء في أحد أحكام المحكمة

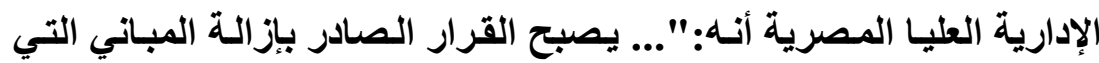
أقامها المطعون ضـده - بحسب الظـاهر - غير قائم على أسـاس سـليم من الواقع والقانون ويكون مرجع الإلغاء عند الفصل في الموضوع، ممـا ينتفي معه ركن الجدية فضلاً عن توافر ركن الاستعجال المتمثل في الأضرار التي في فئي

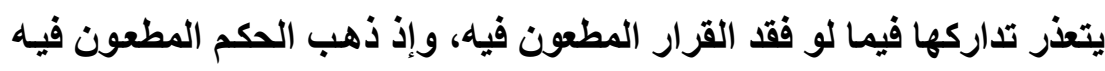

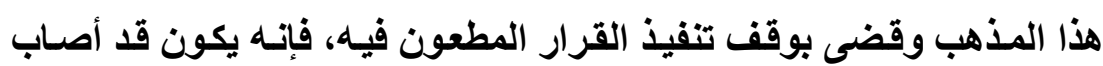

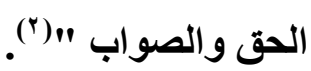

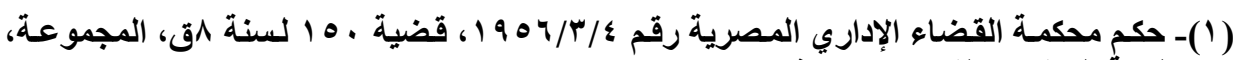

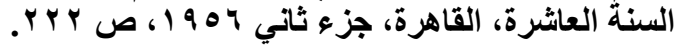

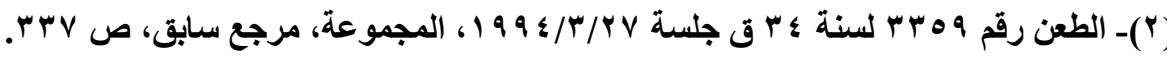




\section{الاملب الثاني \\ الرقابة على التكييف القانوني للأسباب}

بعد أن يتأكد القاضي من الوجود المادي للأسباب فإنه ينتقل إل المرحلة التالية

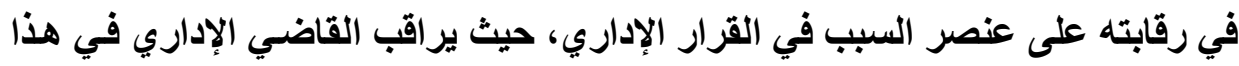

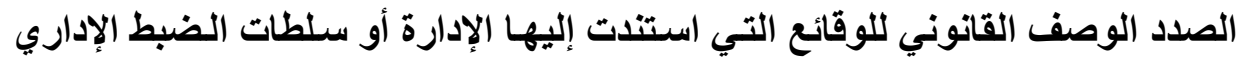

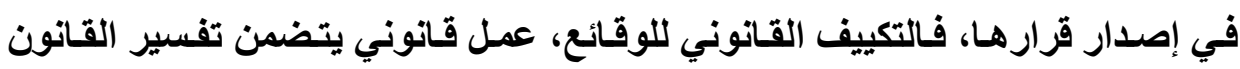
بغرض تطبيقه على واقعة محددة، بنـاءً على ذلك فبإن عملية التكييف التي تقوم بها

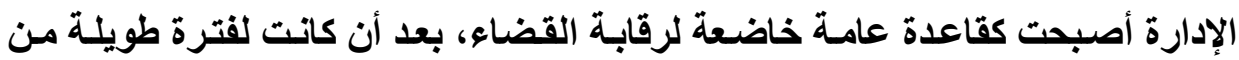

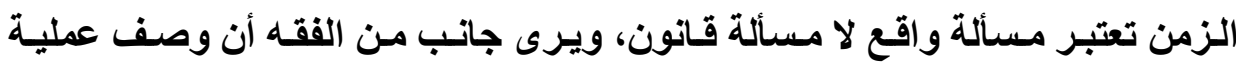

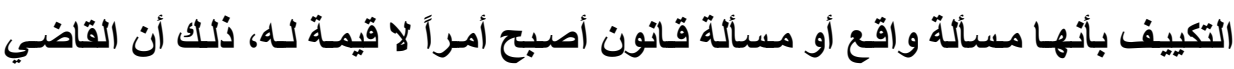

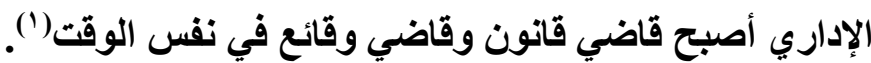
وتبدو الحاجة للتكييف القـانوني عندما يحدد القـانون أوصـافاً معينـة وشروطاً محددة في الوقائع التي تثكّل سنداً للإدارة في إصدار قراراتها، بحيث يجب أن تستجمع

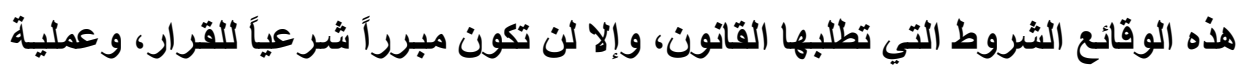

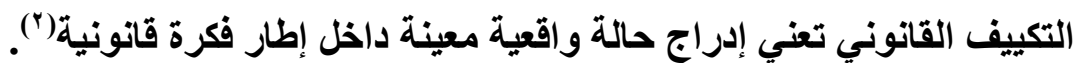
وهذه العملية تستلزم جهداً إنشائياً مهماً من قبل الإدارة والقاضي الإداري، ممـا

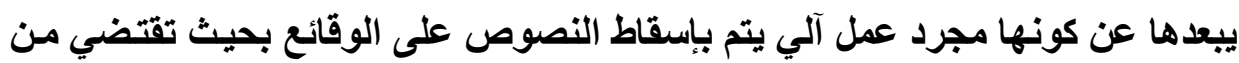
القائم بها تخصيص القاعدة القانونية التي تتسم بالعمومية والتجريد، بإعطائها معنى بإسى

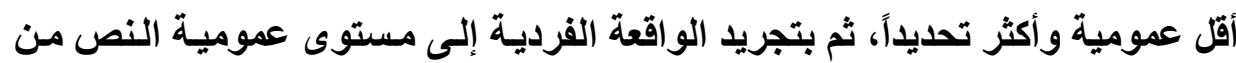

( (1) - د. عـادل أبو الخير، الضبط الإداري وحدوده، رسـالة دكتور اه، حقوق بنـي سـويف، ب9 9 19، ص 9 ץ؟ (ץ) - د. محمد حسنين عبد العال، الرقابة القضائية على قرارات الضبط الإداري، مرجع سابق، ص9 ؛ . 


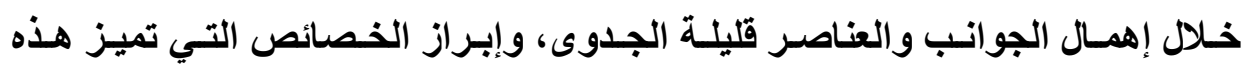

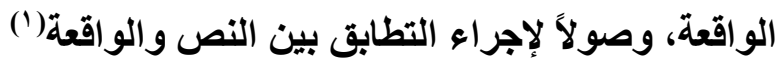

و إذا كان الهدف المحدد لسلطة الضبط الإداري هو المحافظة على النظام العام

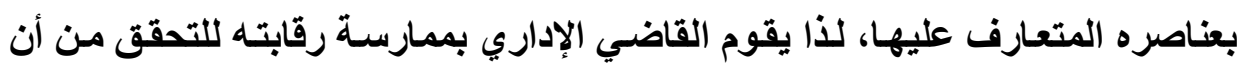

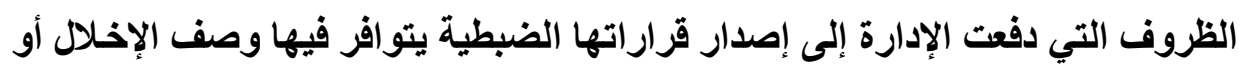

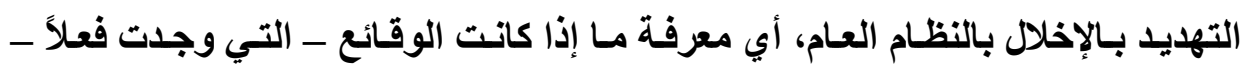

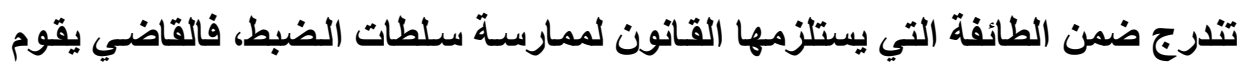
بالتحقق من صحة الوصف القانوني الذي أضفته سلطات الضبط على الوقائع التي

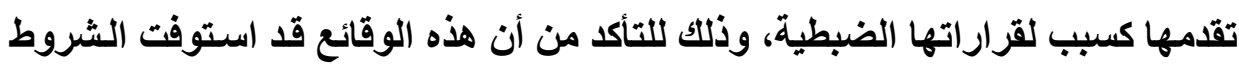
القانونية التي تجعلها مبررة لقرارات الضبط الإداري المتخذة.

وقد بدأ مجلس الدولة الفرنسي في مباشرة هذا النوع من الرقابـة عندما أصدر

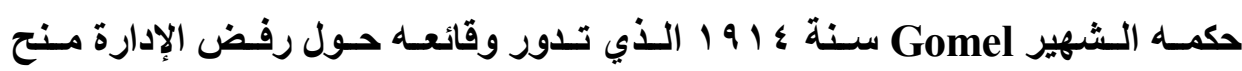
الترخيص بالبناء لأحد المواطنين في منطقة ميدان Beauveau باعتبار هذا الميدان

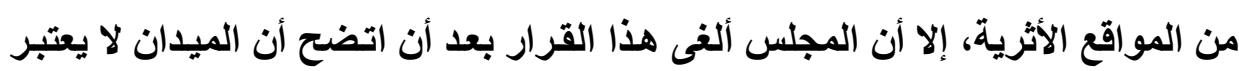

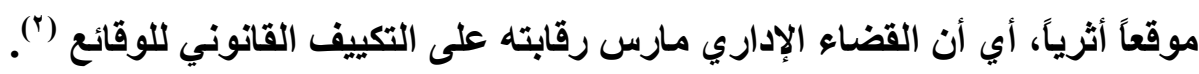
وقد قرر مجلس الاولة الفرنسي فيما بعد أن هناك مجموعة من الأنشطة التي لا

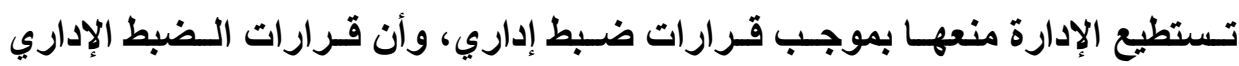

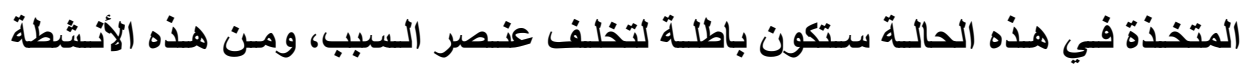

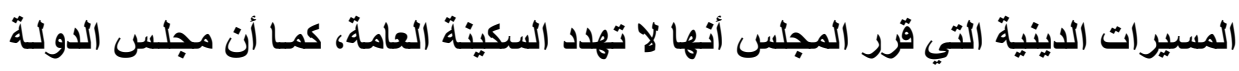

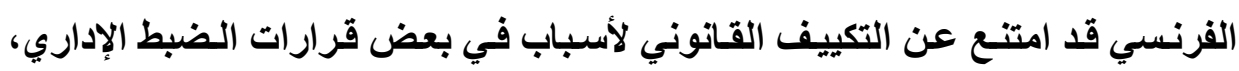


واكتفى بالرقابة على الوجود المادي للوقائع فقط، حيث استثنى الرقابـة على التكييف

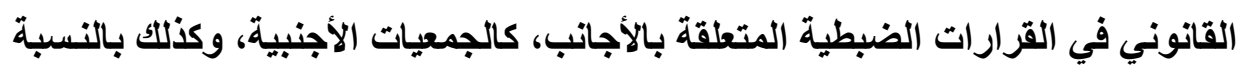

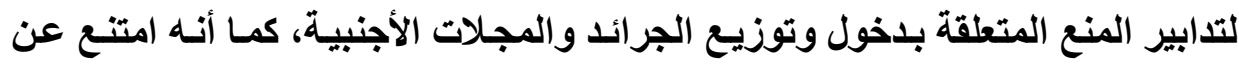
التكييف القـانوني للأسباب في بعض القرارات التي تتسم بطابع فنـي معقد يستلزم

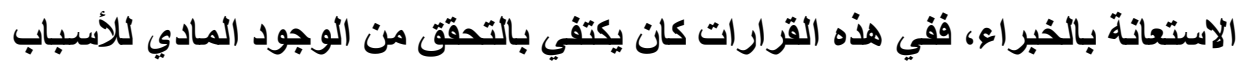

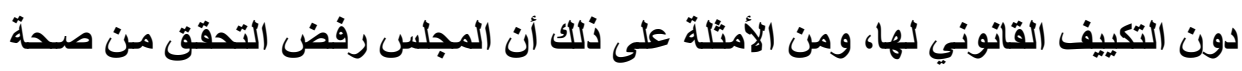

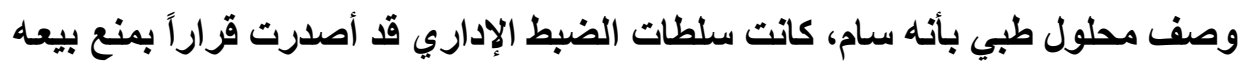

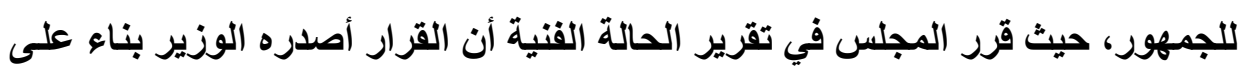

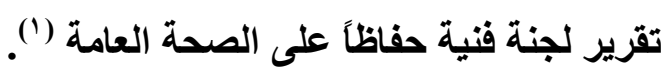
وفي مصر يبسط القضاء الإداري المصري، رقابته على التكييف القـانوني

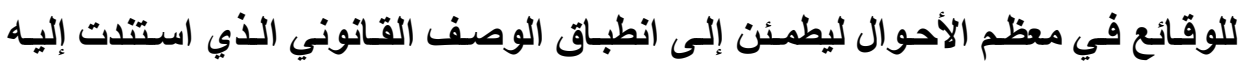

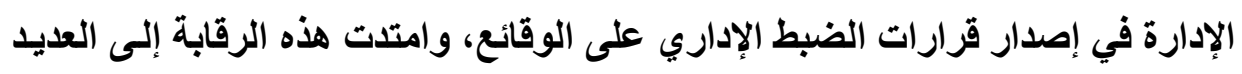

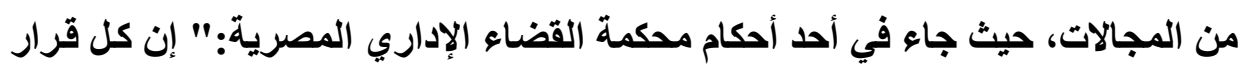

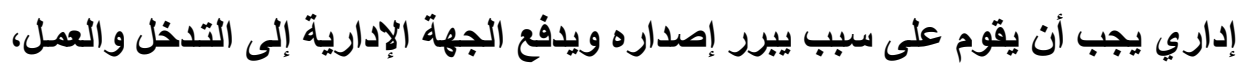

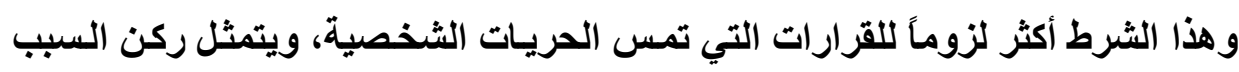

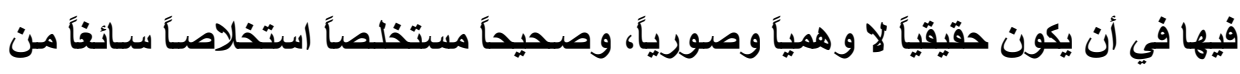

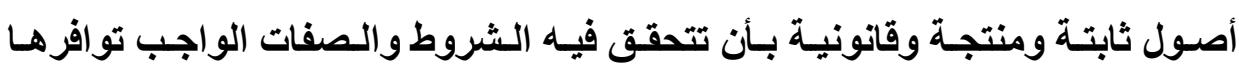

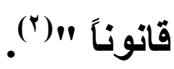

ونشير أخيراً إلى أن التكييف القـانوني للوقائع يوجد عندما يعطي المشرع

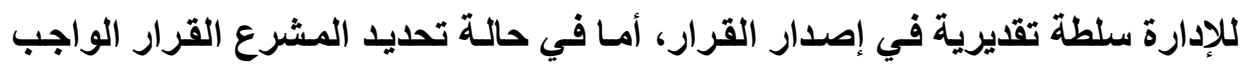

( (1)- د. حلمي الدقدوقي، رقابة القضاء على المشروعية الداخلية لأعمال الضبط الإداري، الإسكندرية،

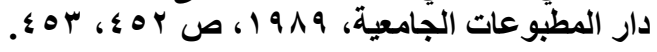

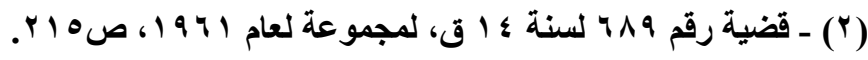


اتخـاذه عنــ حدوث وقـائع معينـة ومحددة فِإن سلطة الإدارة التقديريـة تنعدم في هذه الحالة ويكون تصرفها إما موافقاً للقانون، أو مخالفاً له، غير أنه حتى في إطار السلطة التقديرية للإدارة يمتثع القضاء الإداري في حالات استثنائية عن مراقبة تكييف الإدارة

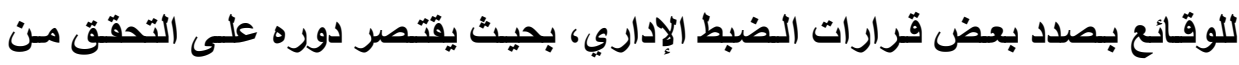
الوجود المـادي للوقائع، دون البحث في صحة الوصف القـانوني الذي أضفته الإدارة

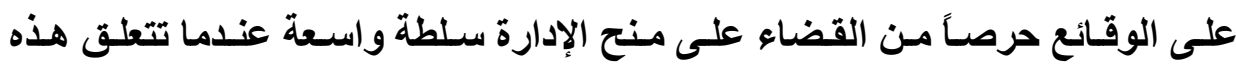
القرارات بأمن الدولة وسلامتها.

\section{الامطاب الثالث}

\section{الرقابة على الملائمة أو التناسب}

يعد هذا الشكل من الرقابـة القضائية على عنصر السبب في القرار الإداري، أقصى درجات الرقابة القضائية على الإطلاق وأوسعها مدى، فالحالة العامة في القـانون

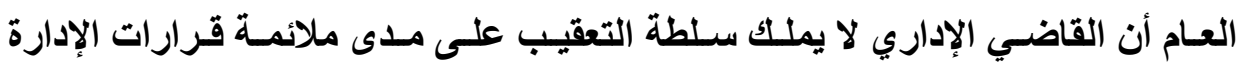

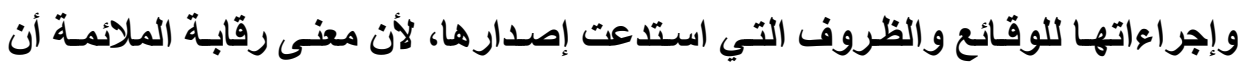

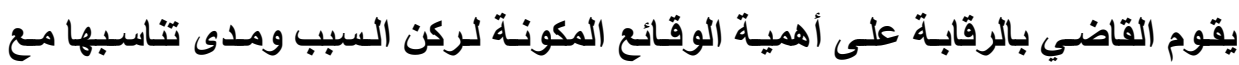

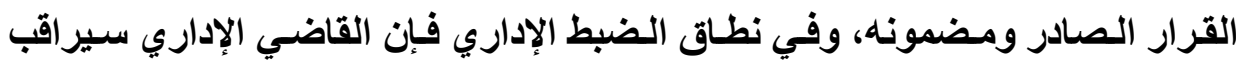
درجة خطورة قرار الضبط الإداري، ومدى تناسب شـدة الإجراء المتخذ من سـلطات الضبط الإداري مع خطورة تهديد النظام العام ('). وواضح هنا أن القاضي الإداري في هذه الحالة سيتدخل في نطاق محظور عليه

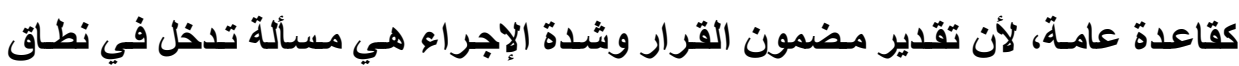

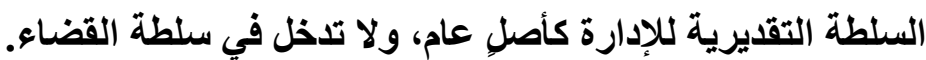

(1) - د. عبد الله طلبة، مبادئ القانون الإداري الجزء الثاني، الطبعة التاسعة عشرة، منشورات جامعة

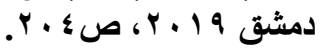


ولكن هنـاك بعض الحسالات الاستثنائية قرر فيها القضاء الإداري بسط رقابته

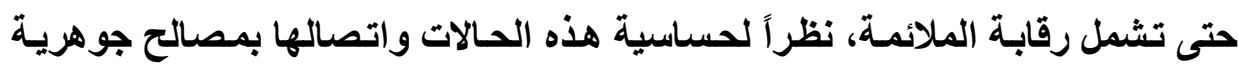

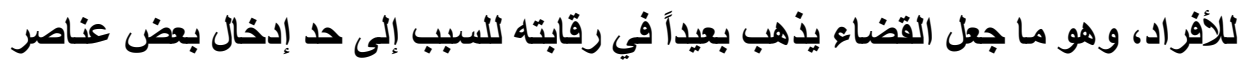

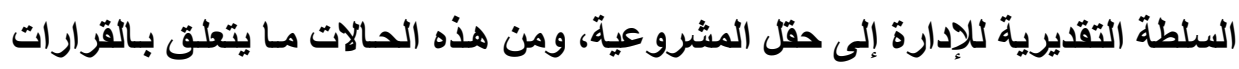
التأديبية والقرارات المتصلة بالحريات العامة(')، وهذه الأخيرة هي التي تهمنا في إطار رقابة القضاء على عنصر السبب في نطاق قرارات الضبط الإداري. وتعرَّف رقابـة الملائمسة بأنها:" رقابـة القاضـي لأهميـة الوقائع المكونـة لركن

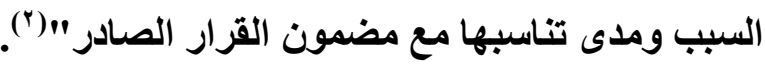
فقد امتدت رقابة القضاء الإداري في كل من فرنسا ومصر على عنصر السبب

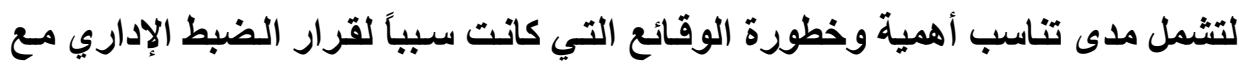

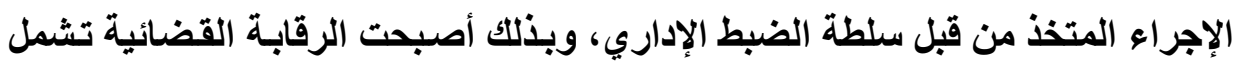
مدى ملائمة وتناسب القرار الذي اتخذته سلطة الضبط الإداري والإجراء الذي قامت بـاء بـه

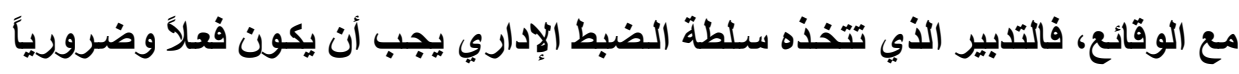

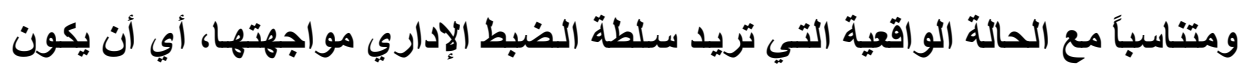

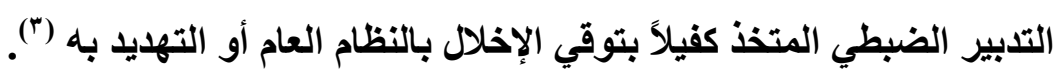
وقد استقر قضاء مجلس الدولة الفرنسي منذ فترة طويلة على أنه ليس للإدارة

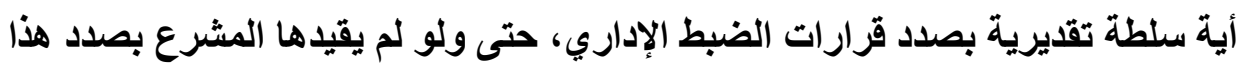

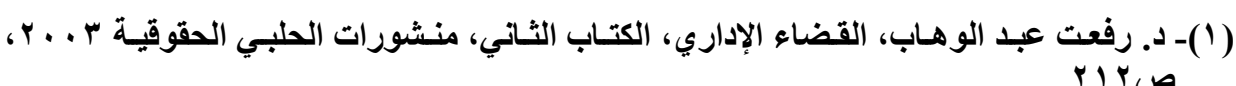

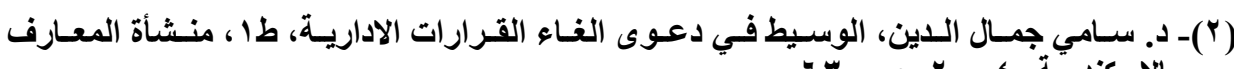

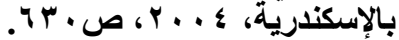

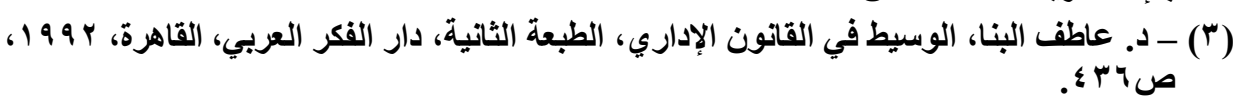


الاختصـاص، لأن تعلـق تـــابير الـضبط بالحريـات العامـة يجعلهـا بعيـدة عـن السلطة التقديرية للإدارة، فهو مقيدة دوماً بالقيام بما هو ضروري للحفاظ على بلى النظام العام' ('). والمبدأ أنـه إذا مـا طعن في أحد تـابير الضبط الإداري المتخذة مـن سـلطات

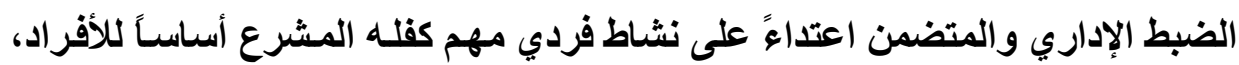

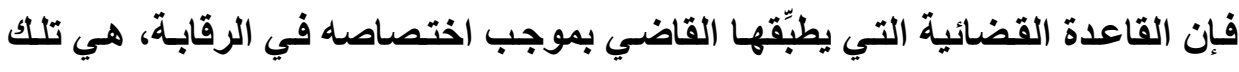
القاعدة التي عبرّ عنها الفقيه الفرنسي ريفيرو بأن " تدبير الضبط لا يكون مشروعاً إلا

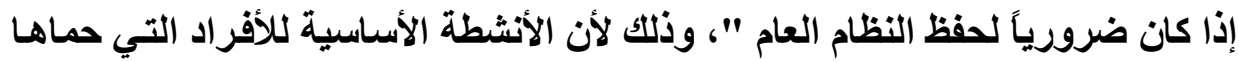

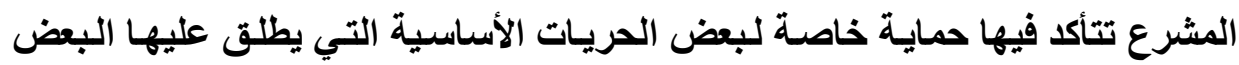

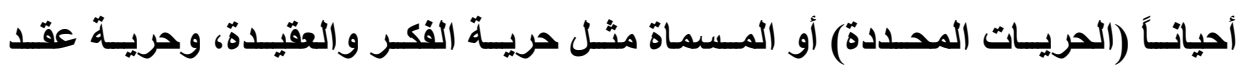

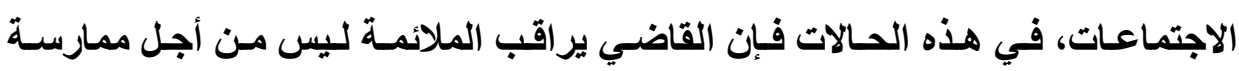

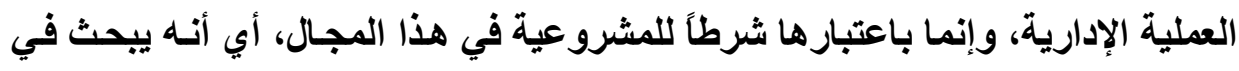

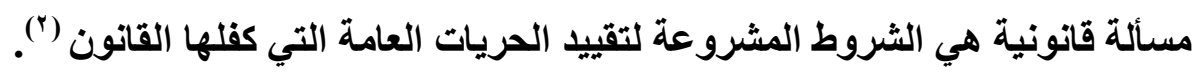

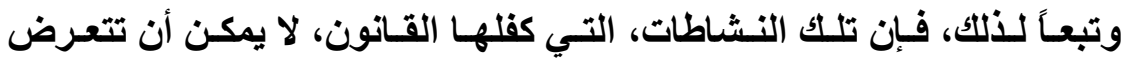

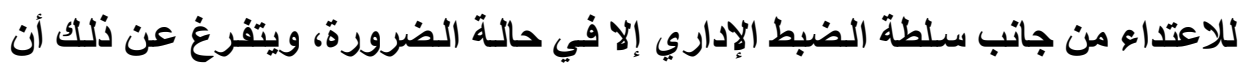
جميع إجراءات الضبط الإداري التي تستهدف تلك الفئة من النشاطات والتي جعلت منها

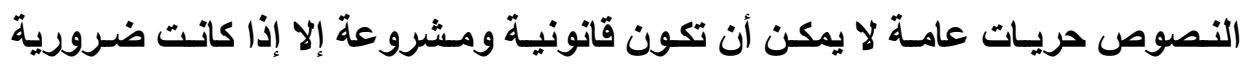

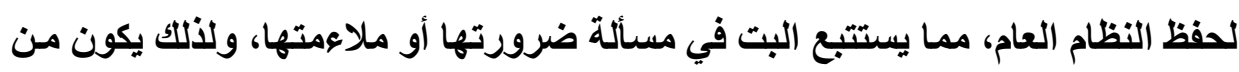

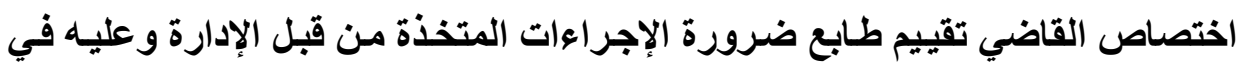
سبيل ذلك تقييم مدى أهمية السبب لتحديد مدى مشروعية الحالة المطروحة أمامـه،

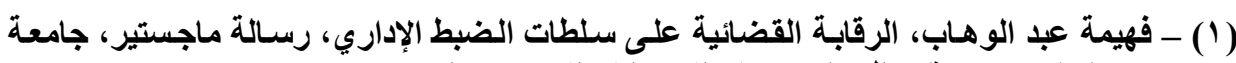

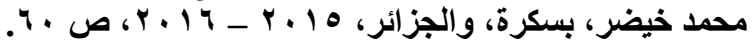

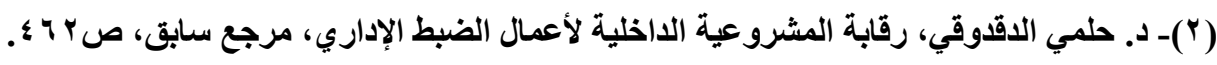


وهنا نصل لذات النتيجة السابقة من أن مراقبة ملائمة الأسباب للوقائع المادية مـا هي إلا مراقبة للمشروعية.

ونجد في قضاء مجلس الدولة الفرنسي العديل من الأحكام والتطبيقات حول ملائمة أو تناسب القرار الإداري الضبطي مع الوقائع في مجال الحريات العامة، وأشـهر

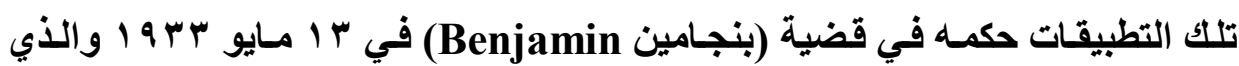
قرر فيه بعد تقييمه لأهمية وخطورة الاضطرابات التي قد تستتبعها المحاضرة بالنسبة

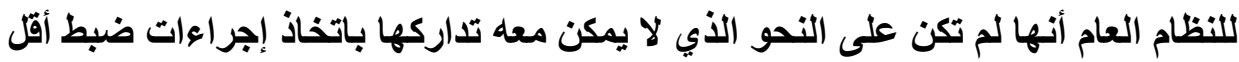

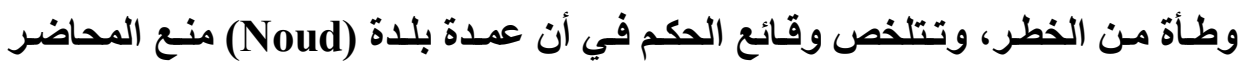

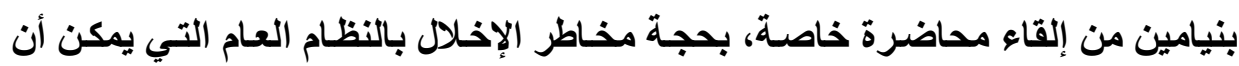

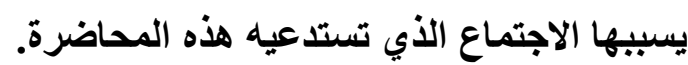

ولاى فحص مجلس الدولة الفرنسي للظروف المحيطة بالاجتمـاع تبين لله أنسه كـان بإمكان السلطات المحليـة المحافظة على النظـام العـام باستخدام قوات البوليس

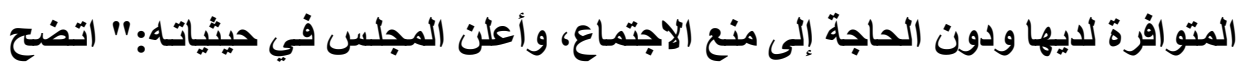

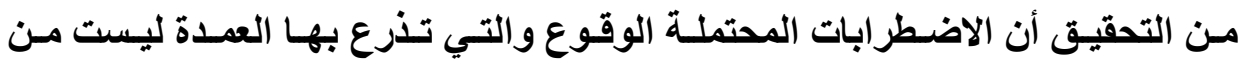

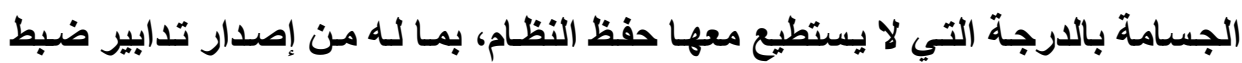

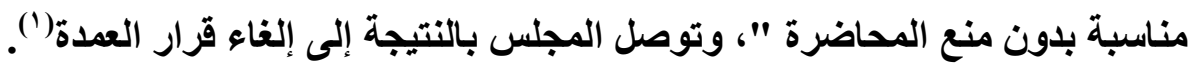

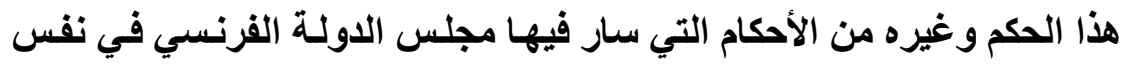

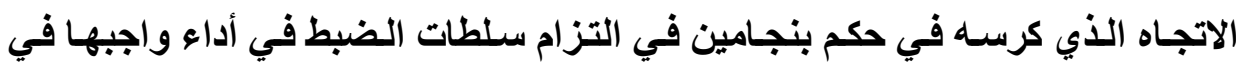
المحافظة على النظام العام بوجوب احترام حريات الأفراد في عقد الاجتماعات والتوفيق بينها بين المحافظة على النظام العام بمـا يستوجب عدم تقييل حرية الاجتمـاع إلا في

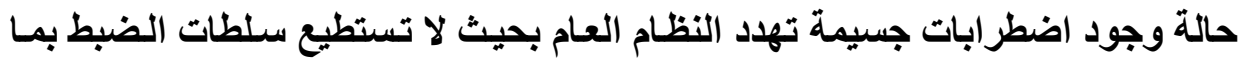
للايها من سلطة اتخـاذ تدابير ضبطية مناسبة تفاديها، ففي هذه الحالة وحدها يمكن

( (1) - د. ثائر معين أحمد، الرقابة القضائية على أعمال الضابطة الإدارية، مرجع سابق، صب 1 ا. 
لـلإدارة منـع الحريـات، ويخضع تقدير الإدارة لأهميـة وخطورة السبب لرقابـة مجلس الاولة...

فإذا تبين للقاضي قيام التناسب بين الإجراءات المتخذة من قبل الإدارة والوقائع

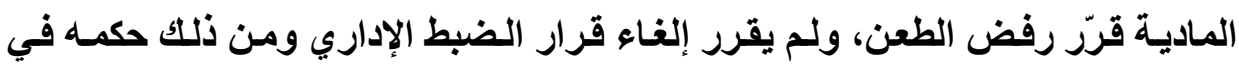
قضية (Bueard)، برفض طلب إلغاء قرار بخطر الاجتماعات حتى الخاصـة التي تعقد

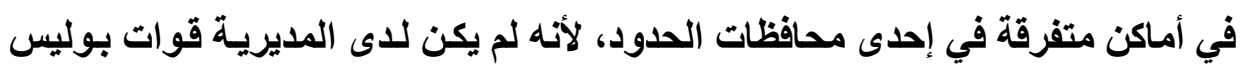

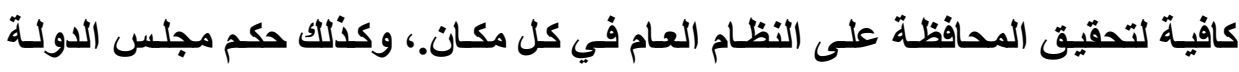

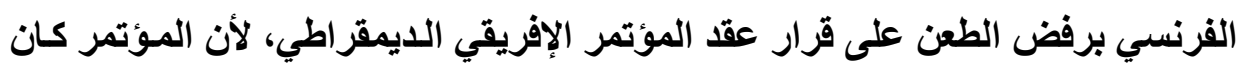
يجري في إقليم (فولتا العليا) الإفريقي وكان من شـأنه، في ظروف ذلتك الإقليم، تهديد

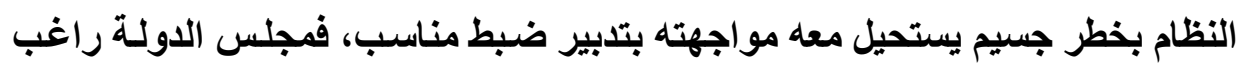

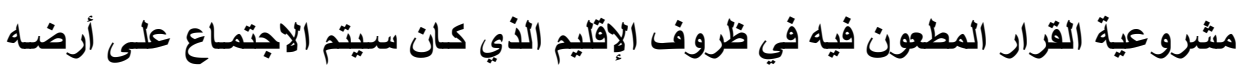

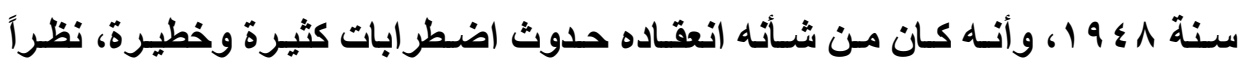

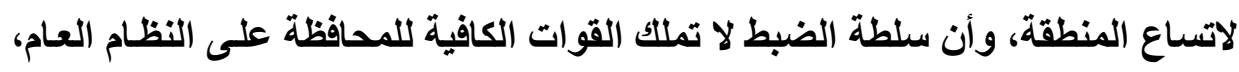

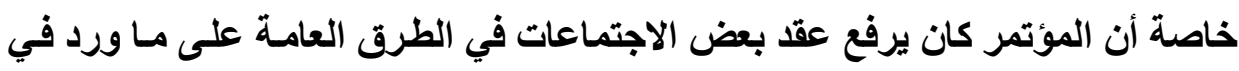
تنظيمه (1) (1) (ن)

وكذلك فإن مجلس الدولة المصري قد بسط رقابته هو الآخر على ملائمسة أو

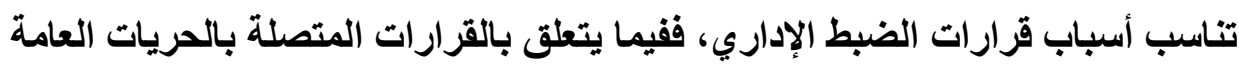

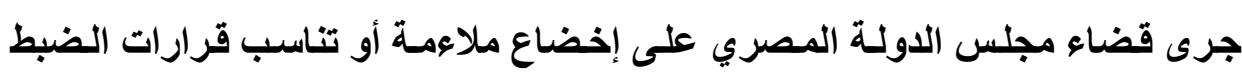

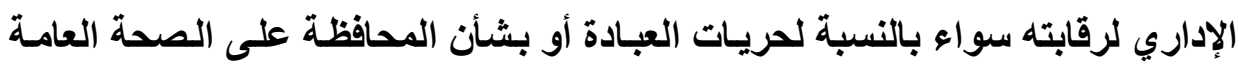

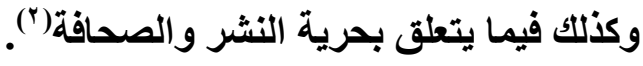

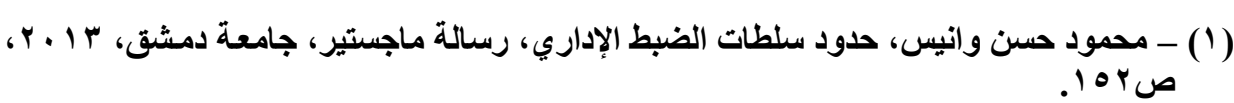

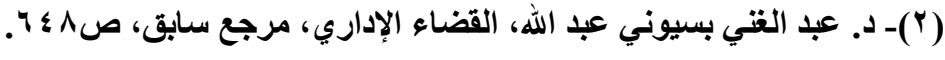


وير اقب القضاء الإداري في هذه الحسالات إلى جانب صـحة الوجـود المـادي

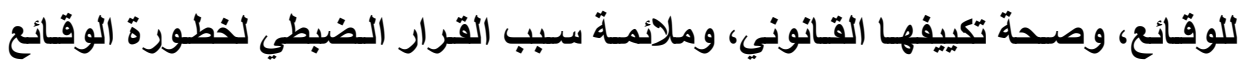

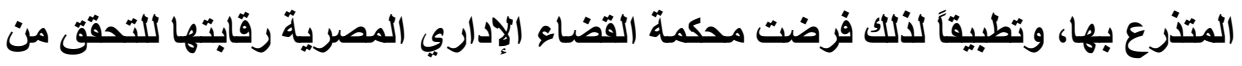

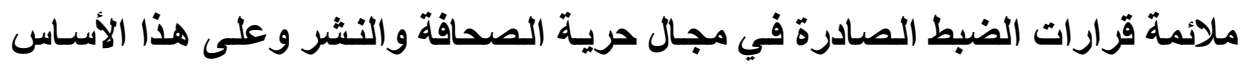

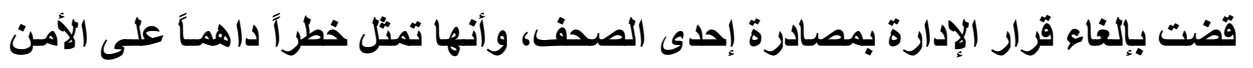

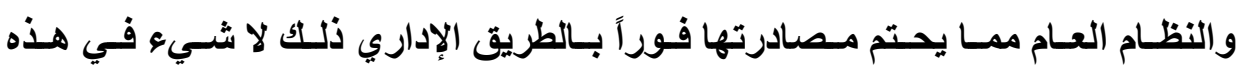

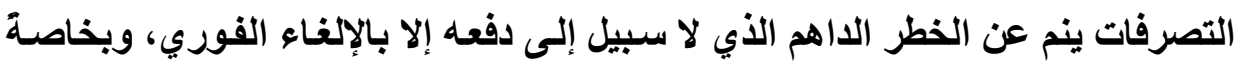

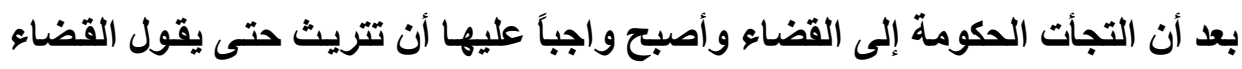

وفي حكم آخر لمحكـة القضاء الإداري المصري أكَّدت فيـه بأن يقتصر تقييد

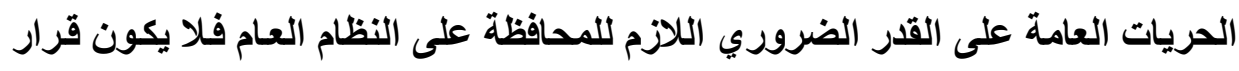

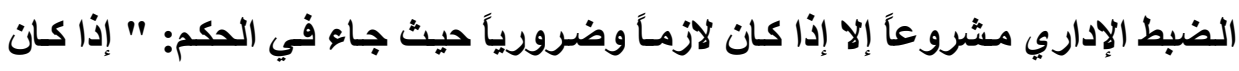
لوزير الداخلية سلطة الضبط الإداري التي تقوم على وسـائل وقائية تهدف إلهاءلى إلى صيانة

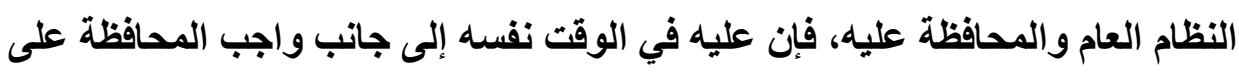

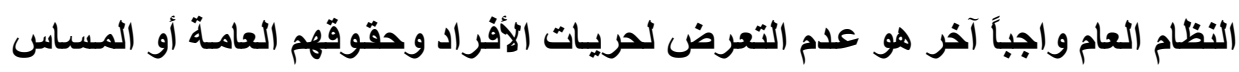

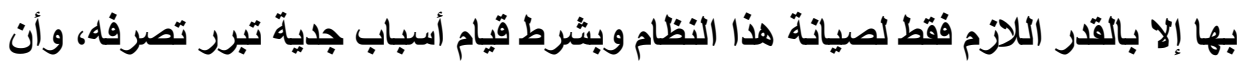

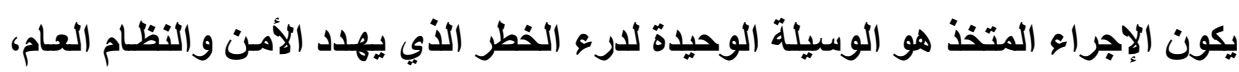

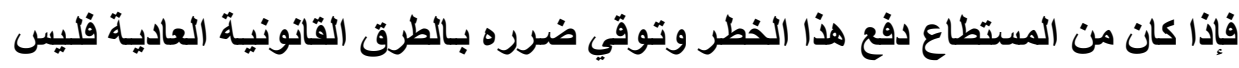

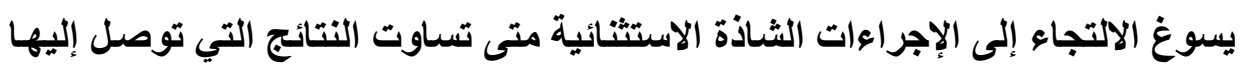

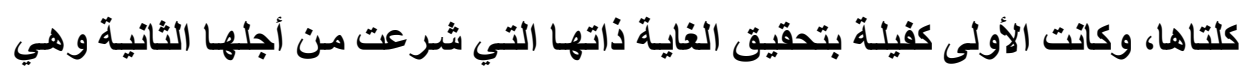


ضمان سلامة النظام العام في نهاية الأمر، وذلك لانتقال الضرورة التي تحتم الالتجـاء إلى الطرق الاستثنائية"(')

وقد استقرت أحكام المحكمة الادارية العليا المصرية على فرض رقابـة الملائمـة

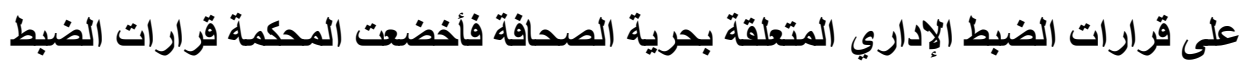

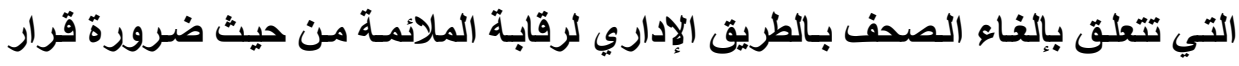

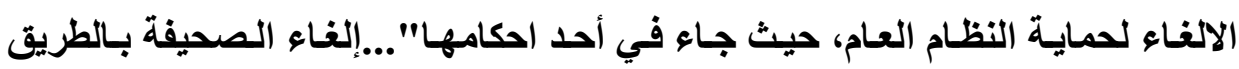

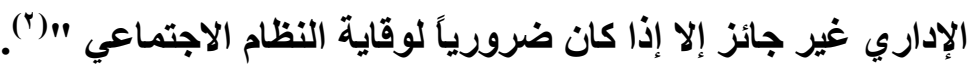

وكـللك الحسال في مجـال حريـة الاجتمـاع، حيث جـاء في أحـ أحكـام المحكمـة

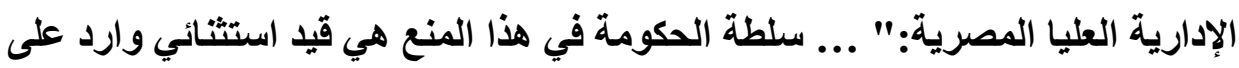

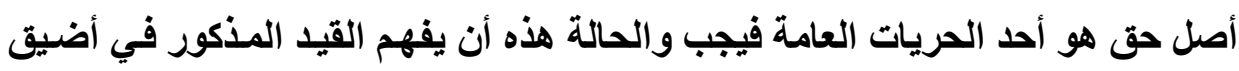

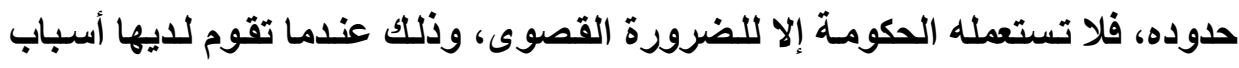
حقيقية لها سندها من الواقع تـل على أن هذا الاجتمـاع من شـأنه حقاً الإخـلال بـالأمن

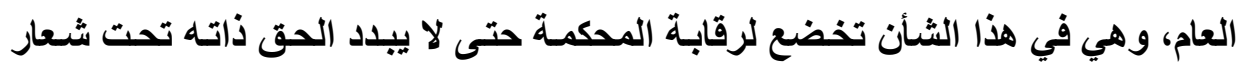

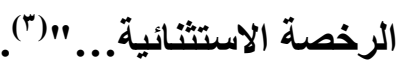

وقبل أن نختم الحديث عن موضـوع الرقابـة على ملائمسة أو تناسب قرارات

الضبط الإداري نشير إلى أن عيب عدم تناسب محل تدبير الضبط مـع أسبابه الواقعية

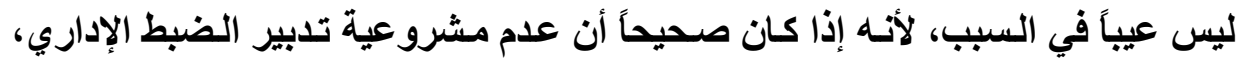
لعدم تناسب محلّه مع سببه، يتقرر بعد تقدير القاضي أسباب التدبير ومحلَه إلا أن الأمر

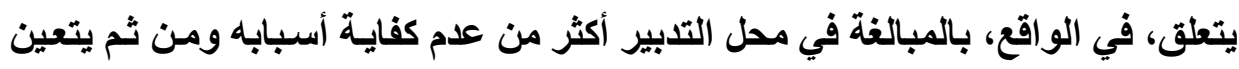

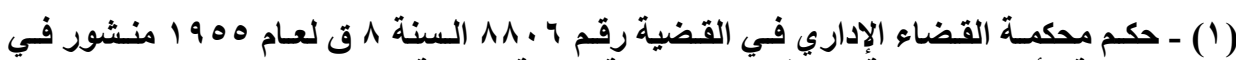

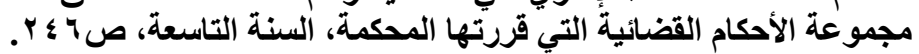

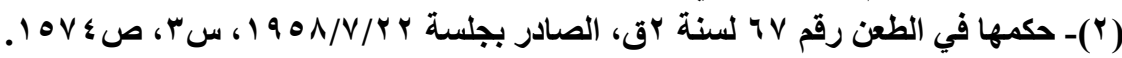

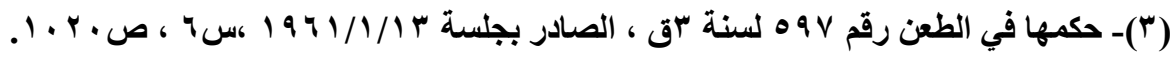


قصر تقرير عدم مشروعية التدبيز، لعيب السبب الواقعي على حساتات عدم الوجود

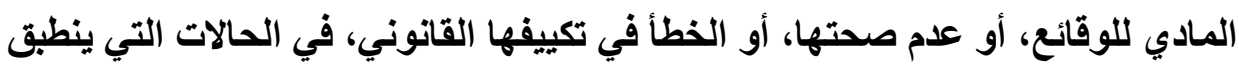

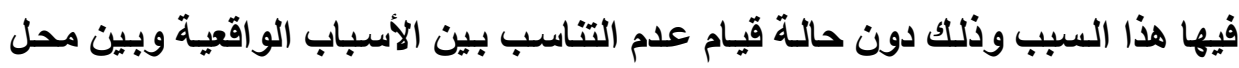

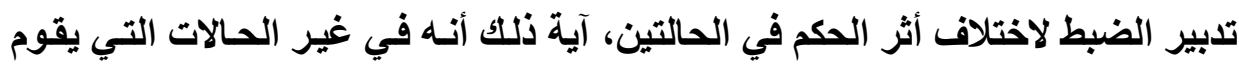

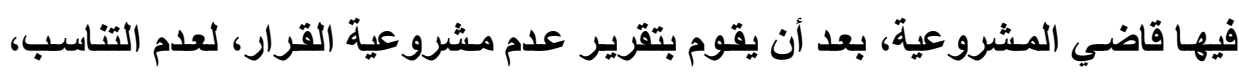

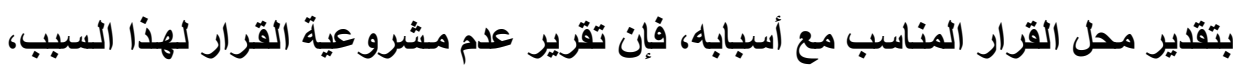

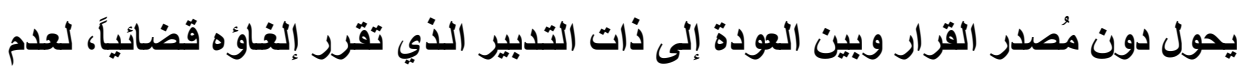

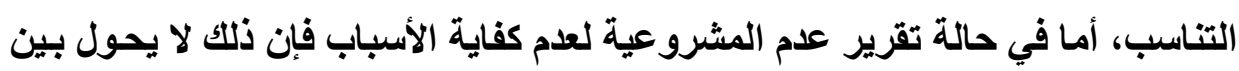
مُصدر التدبير وبين إعادة إصدار ذات التدبير، بذات محله محمولاً على أسباب كافية. على أي حال ومن خلال استقراء اتجاهـات الفقه والقضاء، يجب على سلطة

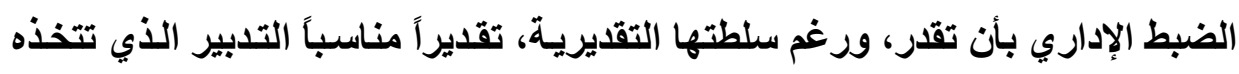
بحيث يتفق مع ما تنطوي عليه أسبابه من تهديد وخطر على النظام العام ذلك أنها وإن إن النابل

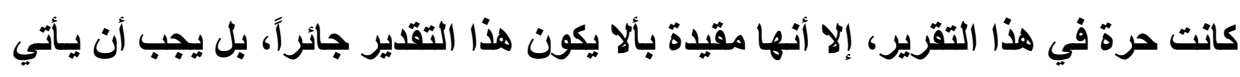

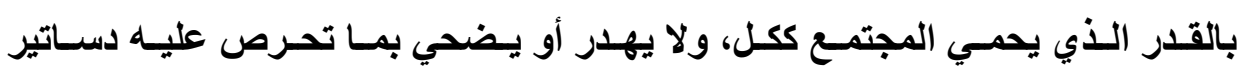

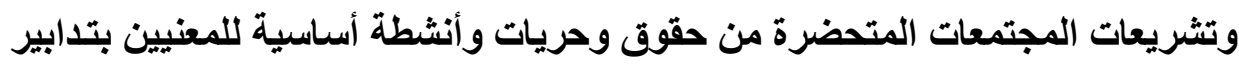

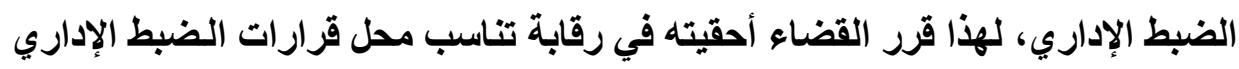
مـع أسبابها، وذلك مـا لم يوجد نص صريح يتفق والاستور والقوانين بالاختصاص

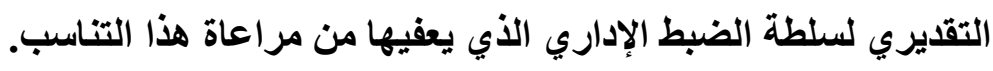
وحيث توجد منطقة الملائمات الإدارية، والسلطة المقيدة، حيث يمارس القاضي رقابـة المشروعية، ولا يجوز التخوف مـن هذا الدور للقاضـي، لأن القضاء هو أحد

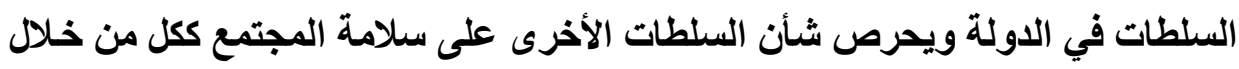

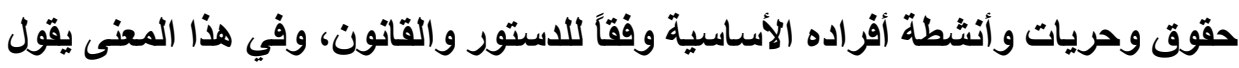
الدكتور حلمي الدقدوقي: 


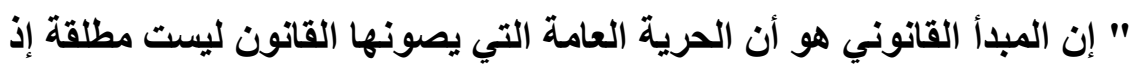

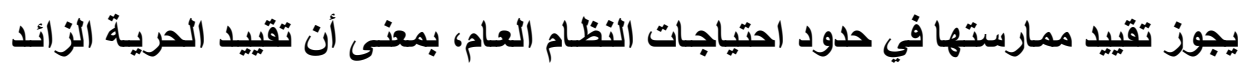

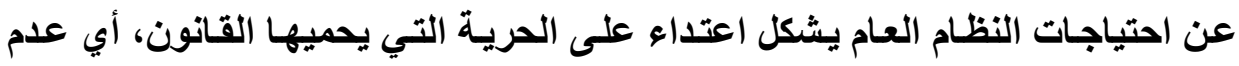

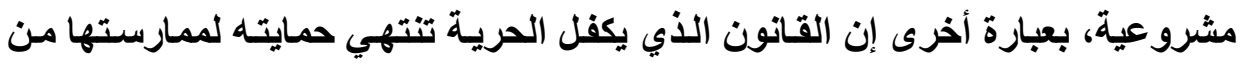

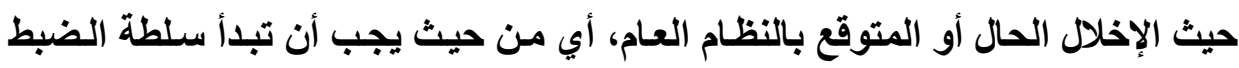

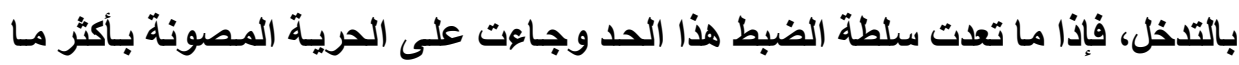
تقتضيه المحافظة على النظام العام كان عملها غير مشروع. وتحديد هذا الحد هو هو

ملائمة التصرف الضبطي بعينها..."(').

ولا بل من أن نذكر أخيراً أن الرقابة القضائية على الوجود المادي للأسباب في

قرارات الضبط الإداري، والتكييف القانوني للأسباب في تلك القرارات تصنف على ألى أنها

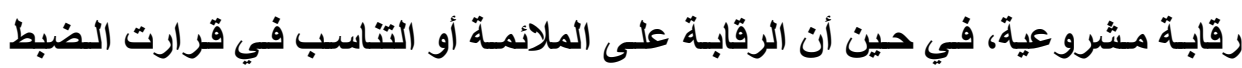

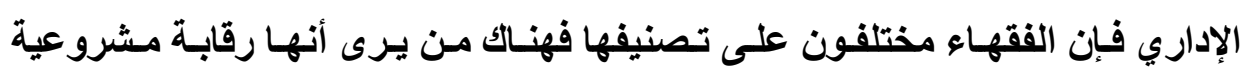

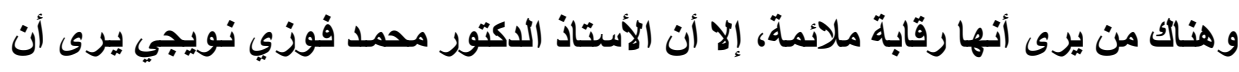

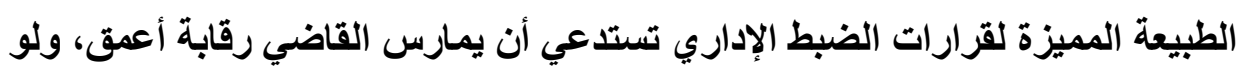

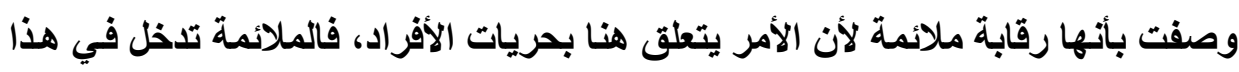

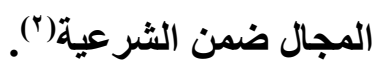

( (1)- د. حلمي الدقدوقي، رقابـة القضاء على المشروعية الداخلية لأعمال الضبط الإداري، مرجع

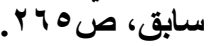
(Y)- د. محمد فوزي نويجي، الجوانب النظرية والعملية للضبط الإداري، مرجع سابق، ص \& ؟Y. 


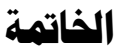

لقد تبين لنا من خلال دراستنا للسبب في قرارات الضبط الإداري ومدى الرقابة القضائية عليه، أن السبب في القرار الإداري إما أن يكون حالة قانونية أو حالة واقعية، وتتمثل الحالة القانونية في القاعدة أو العمل القانوني السابق الذي الذي تستند إليه الإدارة

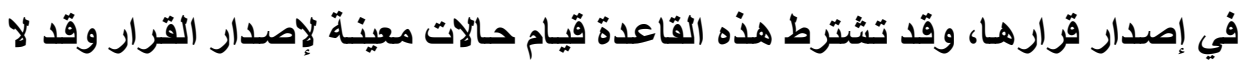

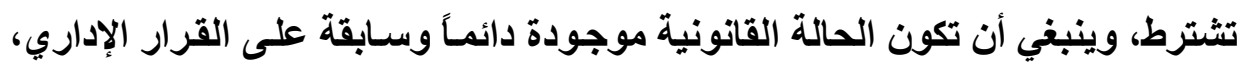

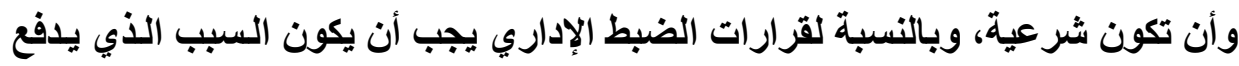

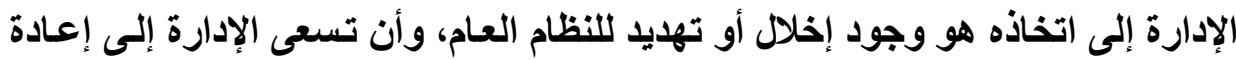
الأمور إلى أمنها والمحافظة على النظام العام بعناصره المختلفة. وتعـد رقابـة القضـاء الإداري على سـبب القـرار الإداري الـضبطي مسن أهـــ الضمانات الأساسية لاحترام سلطات الضبط لمبدأ المشروعية في تصرفاتها، فيقوم

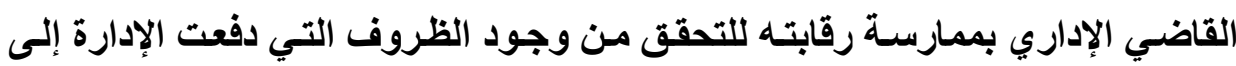

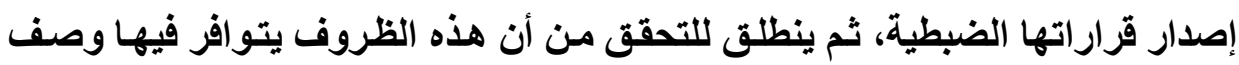

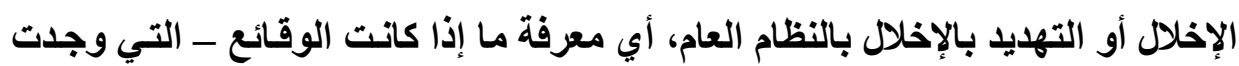

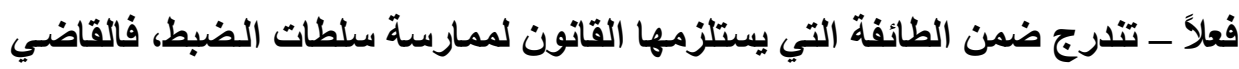
يقوم بالتحقق من صحة الوصف القانوني الذي أضفته سلطات الضبط على الوقائع التي

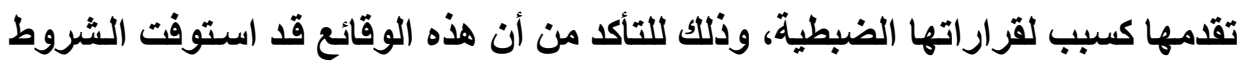
القانونية التي تجعلها مبررة لقرارات الضبط الإداري المتخذة. ونظر اً لخطورة قرارات الضبط الإداري وتأثير هـا على حقوق وحريـات الأفراد

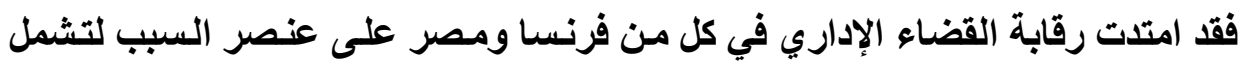

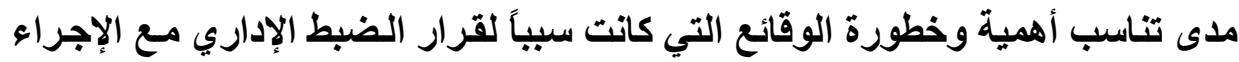

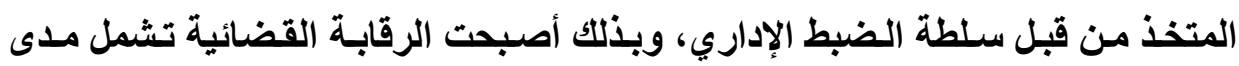


ملائمة وتناسب القزار الذي اتخذته سلطة الضبط الإداري والإجراء الذي قامت بـه مـع

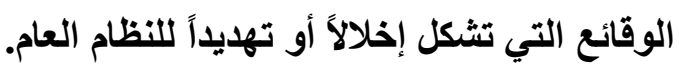

يجدر بنا في ختام هذا البحث أن نورد ما توصلنا إليه من نتائج، ومـا نراه من

$$
\text { توصيات: }
$$

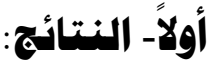

ا - يمثّل السبب في القرارات الإدارية ومنها قرارات الضبط الإداري حالة واقعية أو

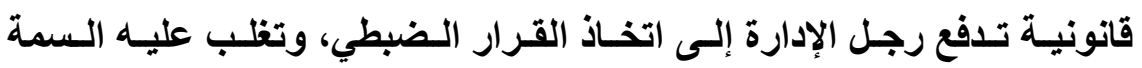

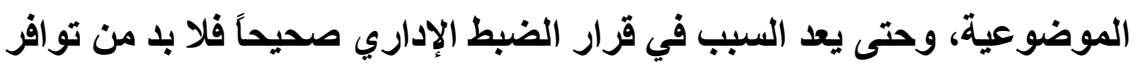
شروط فيه منها أن يكون موجوداً، وأن يكون مشروعاً، وأن يستند على وقائع ثابتة.

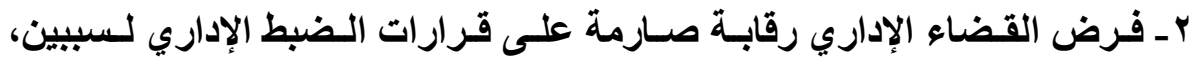

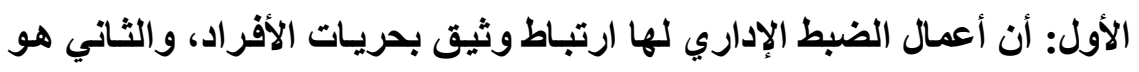

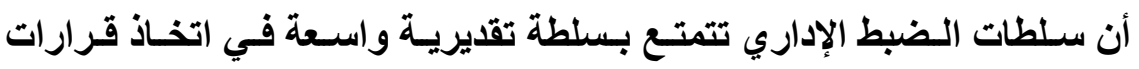
الضبط الإداري، وقد راقب القضاء الإداري عند بسط رقابته على أسباب القرار الضبطي الوجود المسادي للوقائع، والتكييف القـانوني للوقائع التـي تعد سـبياً لقرارات الضبط الإداري، وهي رقابة مشروعية، وقد ذهب القضاء الإداري بعيداً

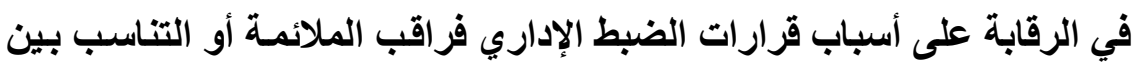
أهمية وخطورة الوقائع التي كانت سبياً لقرار الضبط الإداري وبين الإجراء المتخذ من قبل سلطة الضبط الإداري.

\section{ثانيًاً- التوصيات:}

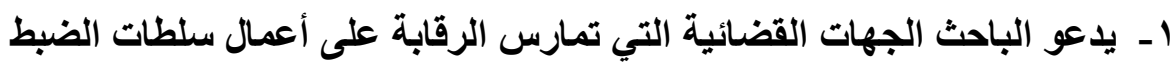
الإداري - سـواء في الـدول التـي تأخـذ بالنظـام القضائي الموحد، أو النظـام القضائي المـزدوج - إلى تعميق الرقابـة القضائية على عنصر السبب في لـي 
القرارات الإداريـة المتخذة مجـال الضبط الإداري وجعلها في جميع الحسالات رقابة ملائمة وتناسب لأن ذلك سيؤدي إلى حماية حقوق وحريات الأفراد. r- يدعو الباحث المشرع ولا سيما في دولة الكويت إلى سن تشريع يوضح فيه

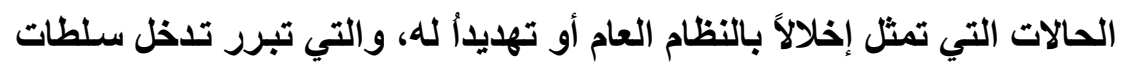

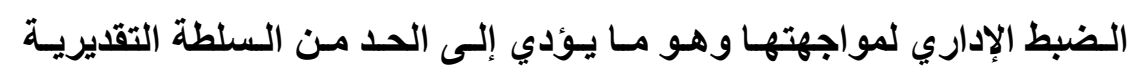

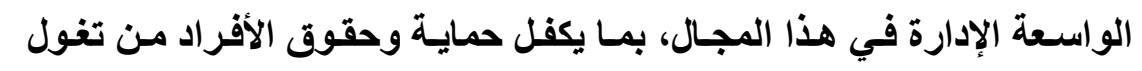

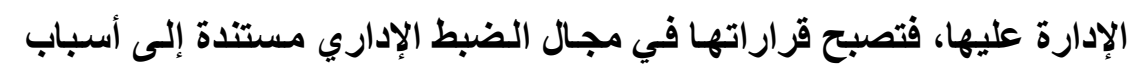

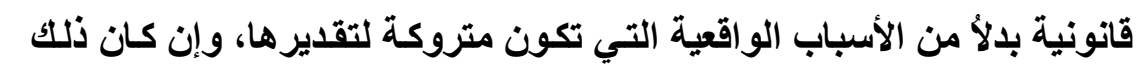

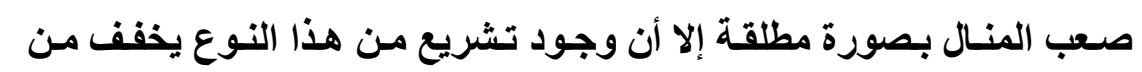
اعتداء الإدارة على حقوق وحريات الأفراد مستتدة إلى أسباب تزعم أنها تثنّّل

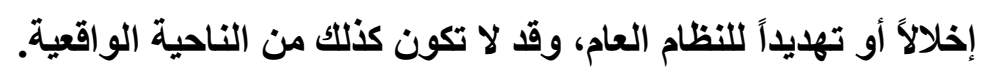




\section{المراجع}

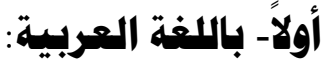

Iـ د. أنيس فوزي عبد المجيد، السبب في القرار الإداري بين النظريـة والتطبيق -

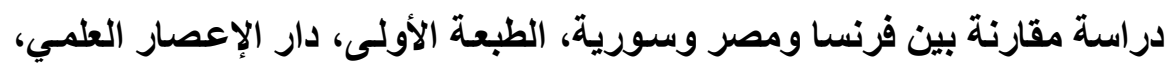

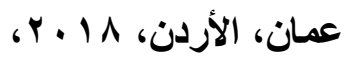

r rــ. حسنين عبد العال محمد، الرقابة القضاية على قرارات الضبط الإداري، الطبعة الثانية، دار النهضة العربية، القاهرة، (دون ذكر تاريخ) الترهابه

بـ د. حلمي الدقدوقي، رقابة القضاء على المشروعية الداخلية لأعمال الضبط الإداري،

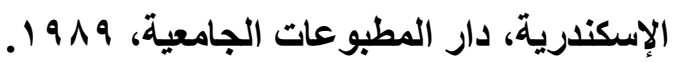

ع ـ د. حمدي ياسين عكاشة، القرار الإداري في قضاء مجلس الدولة، الطبعة الأولى،

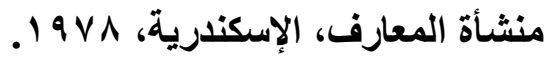

هـ د. خالـد المحمـد، الرقابـة القضائية على الأسبـاب الواقعيـة للقـرار الإداري، بحث

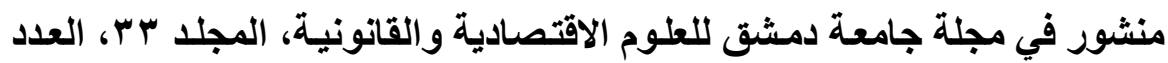

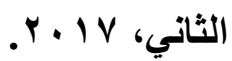

צـ د. خالد خليل الضاهر، القانون الإداري، الكتب الثاني، الطبعة الأولى، دار المسيرة،

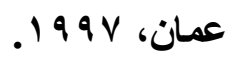

Vـ ـــ رفعت عبد الوهاب، القضاء الإداري، الكتاب الثاني، منشورات الحلبي الحقوقية،

$$
\text { بيروت r +. . . }
$$

^ـ د. زين العابدين بركات، مبادئ القانون الإداري، الطبعة الثانية، مطبعة الريـاض،

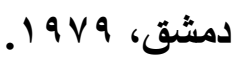


قضاء الملائمسة والسلطة التقديريـة لـلإدارة، الطبعـة الأولى، منشورات جامعـة

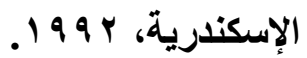

الوسيط في دعوى الغاء القرارات الاداريـة، طا، منشأة المعـارف بالإسكندرية،

• 1 ـ د. سليمان محمد الطماوي:

النظرية العامة للقرارات الإدارية، الطبعة السادسة، دار الفكر العربي، القاهرة،

الوجيز في القانون الإداري (دراسة مقارنة)، القاهرة، دار القكر العربي، و 9 9 أ. 11 ـ د. طعيمة الجرف: القانون الإداري والمبادئ العامـة في تتظيم ونشاط السلطات

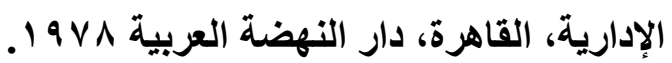

r ا ـ د. عادل أبو الخير، الضبط الإداري وحدوده، رسالة دكتوراه، حقوق بني سويف،

ب ا ـ د. عاطف البنا، الوسيط في القانون الإداري، الطبعة الثانية، دار الفكر العربي،

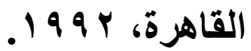

ـ ا ـ عامر بن محمد بن عامر الحجري، الرقابة القضائية على عيب السبب، بحث من

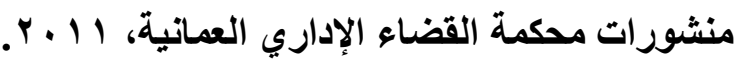

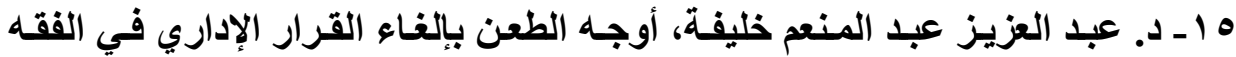

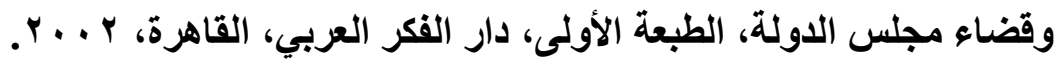
1 ا ـ د. عبد العزيز عبد المنعم خليفة، القرار الإداري في قضاء مجلس الدولة، الطبعة

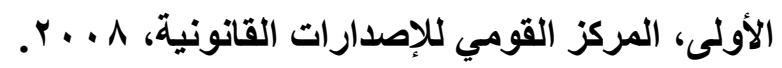
ا ـ د. عبد الغني بسيوني عبد الله: القانون الإداري، دراسة مقارنـة لأسس ومبـادئ القانون الإداري وتطبيقاتها في

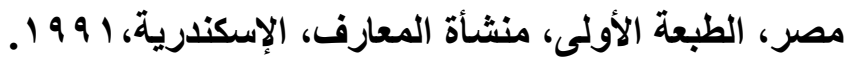


ولايـة القـضاء الإداري علـى أعمـال الإدارة، قـضاء الإلغــاء، منسشأة المعـارف،

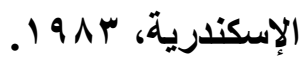

1 1 ــ. عبد الله طلبة، مبـادئ القـانون الإداري الجزء الثاني، الطبعة التاسعة عشرة،

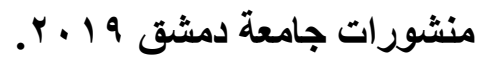

9 اـ د. علـي خطـار شطناوي، تسبيب القرارات الإداريـة في فرنسـا والأردن، بحث

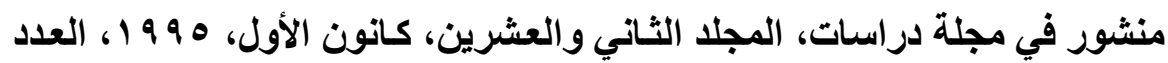
السادس والعشرين.

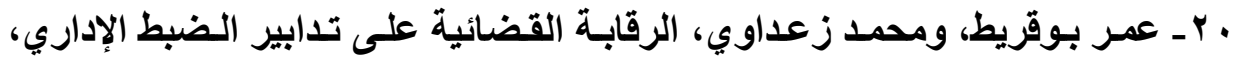

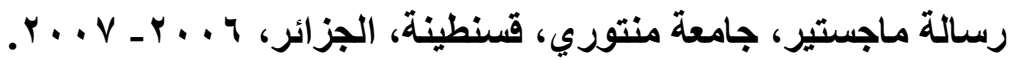

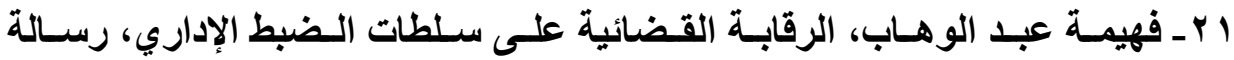

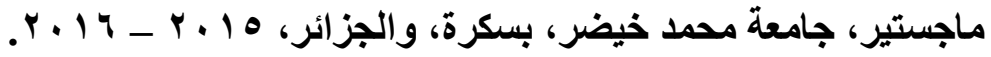

Y Y ـ د. ماجد راغب الحلو، القانون الإداري، الطبعة الأولى دار المطبوعات الجامعيـة،

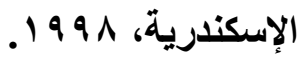

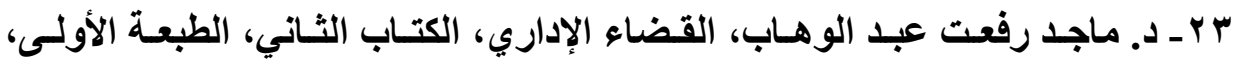

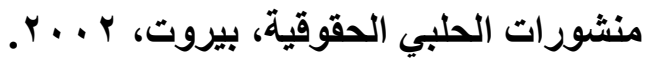

r ץ ـ محمد بن مرهون بن سعيد الذيب المعمري، تسبيب القرارات الإداريـة، (دراسـة

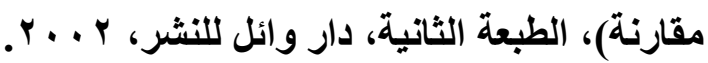

ع ؟ ـ د. محمد حسنين عبد العـال، فكرة السبب في القرار الإداري ودعوى الإلغـاء،

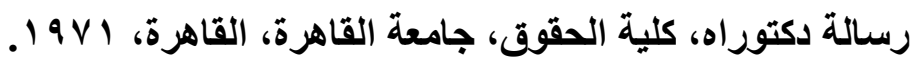

ه ب ـ د. محمد عبد العال السناري ، القرارات الإداريـة في المملكة العربية السعودية،

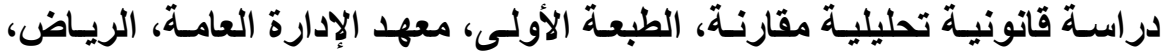

צ ץ ـ د. محمد عبد العال السناري، مجلس الدولة والرقابة القضائية على أعمـال الإدارة

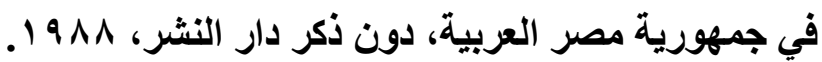




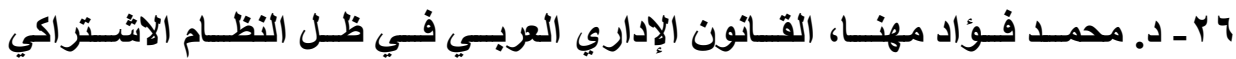

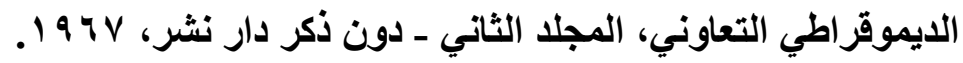

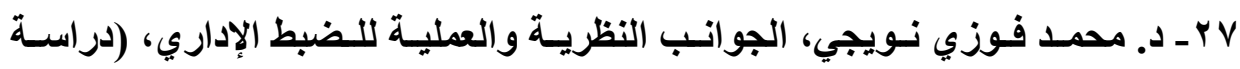

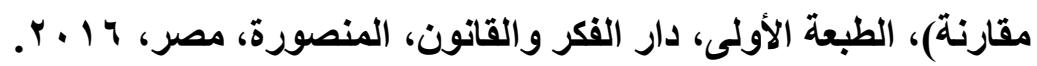

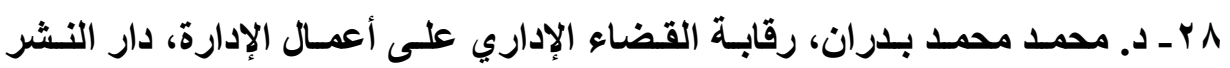

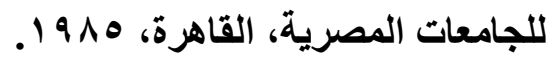

9 ץ ـ محمود حسن وانيس، حدود سلطات الضبط الإداري، رسـالة ماجستير، جامعة

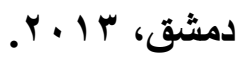

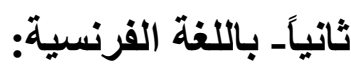

1- Bonnard (R), Précis de droit public, 6 édit, Paris, 1944.

2- Delubadère (A.), Traitè èlèmentaire de administratife, 3,edit, L.G.D.J - T.1- 1967.

3- Guillaume Bhanc: - "Motifs et motivation des decisions administratives" - R.A. 1998

4- Hauriou (M),Précis de droit administratif et de droit public, 12, edit, Paris, 1933.

5- Vedel (G), Essai sur la nation de cause en droit administratife, Thèse, University de Toulouse, Facultè de droit, 1934. 